FILOLOGIJA 70, Zagreb 2018.

UDK 811.163.42'374:801.6 Vrančić, F. https://doi.org/10.21857/90836cwg4y Izvorni znanstveni članak Rukopis primljen 15. IV. 2018.

Bojan Marotti

Prihvaćen za tisak 24. IX. 2018.

Zavod za povijest i filozofiju znanosti HAZU

Ante Kovačića 5, HR-10000 Zagreb

marotti@hazu.hr

bojan.marotti@zg.t-com.hr

\title{
O NADSLOVCIMA NA HRVATSKIM RIJEČIMA U VRANČIĆEVU RJEČNIKU
}

Vt Vocalium quantitatem, \& aliquarum Confonantium litterarum fonum expri〈pri〉meremus: noluimus eos imitari, qvi more Græcorum lineolis, vel Hebræorum, qvi punctis utuntur. Nam hæ linex, \& puncta facilius immutantur, vel eliduntur, quàm à plerifqve intelliguntur. Commodius vifum est, eas duplicare, nempe fic: Aa, ee, ij, oo, uu. (Vrančić 1606./1995:116) ${ }^{1}$

U svome je petojezičnome rječniku, objelodanjenu u Mletcima pod naslovom Dictionarium quinque nobilissimarum Europae linguarum (1595.), Faust Vrančić pri zapisu hrvatskih riječi mjestimice rabio i nadslovke. Posrijedi su tri znaka - oštri, tupi i zavinuti - naslijeđena iz tradicije grčkih gramatika. U prilogu se razmatraju sve hrvatske riječi koje su u Vrančićevu rječniku obilježene nekim od triju spomenutih nadslovaka. Pri tome se pokušava odgonetnuti njihovo "značenje", tj. odgovoriti na pitanje je li poraba svakoga od tih triju znakova u Vrančićevu rječniku ustaljena. Pokaže li se da jest, otvara se novo pitanje: je li na osnovi njihove porabe, no ostajući strogo unutar skupa obilježenih riječi, tj. ne izlazeći "izvan korpusa", te samo na osnovi njihovih uzajamnih odnosa, bez "komparativnoga materijala" uzetoga iz naših narječja (Putanec 1971:11), moguće opisati naglasni sustav koji je njima trebao (ili mogao) biti zapisan. Raščlamba pokazuje da takav opis nije moguće podastrijeti - sve da se u obzir uzmu i udvajanje samoglasnika i udvaja-

1 Ovaj je prilog u velikoj mjeri proširena, znatno izmijenjena i dotjerana inačica izlaganja održanoga na Međunarodnome znanstvenome skupu Faust Vrančić i njegovo doba: U povodu 400. obljetnice objavljivanja Novih strojeva Fausta Vrančića (Vodice Šibenik, 22. - 23. rujna 2015.). To je izlaganje objavljeno u istoimenome zborniku (ur. Marijana Borić, Zrinka Blažević i Bojan Marotti, Memorijalni centar »Faust Vrančić«, Prvić Luka, 2018., str. 101-126). Cjeloviti se zapis knjigopisne jedinice može naći u Popisu uporabljenih djela na kraju ovoga priloga. 
nje suglasnika u zapisu pojedinih primjera - i to upravo zbog neustaljene porabe triju navedenih nadslovaka. U Dodatku se donosi popis svih obilježenih riječi iz Vrančićeva rječnika, kao i usporedba s odnosnim primjerima iz Lodereckerova djela Dictionarium septem diversarum linguarum (1605.).

\section{Predmet i pristup}

Pobrajajući "posebnosti" Vrančićeva jezika, u poznatome članku "Apostile uz >Dictionarium quinque nobilissimarum Europe linguarum" (1595) Fausta Vrančića hrvatski filolog i leksikograf Valentin Putanec kao jednu od tih posebnosti navodi i naglasak pa s time u vezi kaže ovako: »O Vrančićevu akcentu treba pisati posebnu studiju na osnovi njegovih djela, i ona bi mogla biti vrijedan prilog za kronologiju nekih pojava u hrvatskosrpskoj akcentuaciji« (Putanec 1971:12). Putanec pri tome razmatra nekoliko primjera, u kojima na osnovi Vrančićeva zapisa pojedinih riječi "prepoznaje" ili "uspostavlja" naglasak koji je Vrančić, prema njegovu mišljenju, namjeravao zapisati te istodobno obrazlaže i svoj pristup, iznoseći na koji je način, općenito uzevši, to moguće (u)činiti. Evo kako glasi taj malo duži ulomak:

»Može se [naglasak - B. M.] deducirati na osnovi dvostručenja vokala (dužina) te konzonanata (kratkoća) i komparativnog materijala dobivenog na osnovi proučavanja naših dijalekata. Osim toga autor upotrebljava i akcenatske znakove koji nam omogućuju određivanje njegovih akcenata. To su znakovi ', ' , ’. Na osnovi ovakva označivanja i uspoređivanjem sa štokavskim i čakavskim akcentima možemo gotovo uvijek odrediti koji je akcenat mislio staviti Vrančić na svoje riječi: múka »labor « treba čitati müka, a mukà »brašno« kao mūkà (usp. u Životu 86 vazmi muukee, tj. čitaj mūkẽ), meàs čitaj kao mejâš, a lóv kao lôv, peet čitaj pêt, bitti kao bïti, peest kao pêst, od loze i od lozee kao lozê, laan kao lãn, genitiv lanà kao lanä, laaxacz kao lážac (kanovački?, usp. štok. làžac, za kanovački u Šibeniku usp. Hraste, Filologija 1, 63), hotè kao hotê, szramotà kao sramotä.« (Putanec 1971:11-12)

Svatko će se jamačno složiti s time da o Vrančićevu "akcentu" treba pisati "posebnu studiju". No koliko to može biti osjetljiv, pa i mukotrpan posao, pokazuje upravo navedeni ulomak iz Putančeva članka. Naime, u tome je ulomku lako uočiti znatne nedosljednosti. Prije svega, iz raščlambe proistječe da dva različita nadslovka ${ }^{2}$ mogu imati isto značenje, ali i to

2 U ovome se prilogu dosljedno rabi riječ nadslovak za sve znakove koji se zapisuju »iznad slova«. Pojam nadslovka valja strogo razlikovati od pojma naglaska, jer nije a priori jasno što se takvim znakovima doista označuje: naglasak (kao svežanj razlikovnih obilježja), kakvo (razlikovno) naglasno obilježje, primjerice kračina ili dulji- 
Bojan Marotti: O nadslovcima na hrvatskim riječima u Vrančićevu rječniku

da jedan te isti nadslovak može imati dva značenja. ${ }^{3}$ Primjerice, oštri znak u riječi múka, koja znači 'napor', 4 'trud' (latinski labor), valja odčitati kao müka, tj. kao kratkosilazni naglasak, kojim se dakle označuje naglašena kračina, no tako treba odčitati i tupi znak u riječi mukà ('brašno', latinski farina), naime kao mūkà (valja pri tome uočiti da u zapisu mukà duljina samoglasnika $u$ ničim nije obilježena). $S$ druge strane, isti taj tupi znak u riječi meàš valja odčitati kao silazno naglašenu duljinu, tj. kao mejâš, kako treba odčitati i oštri znak u riječi lóv, tj. kao lôv. No silazno naglašena duljina u riječima peet i peest obilježena je udvajanjem samoglasnika $e$, dakle ee, pa te zapise valja odčitati kao pêt i pêst. To pak znači da se silazno naglašena duljina može obilježiti na tri načina: tupim znakom (meàš), oštrim znakom (lóv) i udvajanjem samoglasnika (peet, peest). Ali i (silazno) naglašena kračina može se obilježiti trima načinima, naime oštrim znakom (múka), tupim znakom (mukà) te udvajanjem suglasnika, kako se vidi iz zapisa bitti, koji pak treba odčitati kao bìti. Nadalje, udvojenim se samoglasnikom može obilježiti i visokouzlazna duljina, naime tzv. neoakut ili čakavski akut, ${ }^{5}$ kako se vidi iz primjera muukee, koji treba odčitati kao mūkẽ (uočiti je ovdje da je u zapisu muukee duljina samoglasnika $u$ obilježena njego-

na samoglasnika, ili pak nešto treće. Zapravo, a priori nije jasno ni to rabe li se spomenuti znakovi na prozodijskoj ili na neprozodijskoj razini. Vidi o tome potanje u svojevrsnome "tekstološkome priručniku" što ga je za potrebe niza Stoljeća hrvatske književnosti sastavio Josip Vončina i to poglavlje Nadslovci i naglasci (1999:171-178). Usp. npr. rečenicu: »Davno je uvedeno da se u tekstovima hrvatskoga dijalektalnog pjesništva čakavske grane nadslovcima obilježuju naglasne osobine« (isto, 174). Ili pak ovu: »Ipak, bit će korisno provesti najmanju prijeko potrebnu mjeru nadslovaka: koja pokazuje naglasne opreke« (isto, 175). Usp. također Marotti 2013:I.11.

3 To da nadslovak »može imati dva značenja«, znači zapravo to da se može rabiti na dva različita načina.

4 Značenje pojedine riječi redovito navodim $u$ jednostrukim navodnicima, a njezin lik (saussureovski rečeno signifiant) kosopisom, kao u primjeru: riječ (tj. lik) zemlja znači 'zemlja', a i riječ (tj. lik) terra znači 'zemlja' (samo u drugome sustavu).

5 Potanje o imenu toga naglaska vidi Marotti 2013:I.277-278. O pojmovima visokouzlaznosti i dubokouzlaznosti, kao i o njihovoj razlici vidi László 1996b:433-438, poglavlja Dugouzlaznost i Raznomjesnost oviska. Pokojni je profesor László razlikovao stari hrvatski visokouzlazni (upravo "visoki uzlazni") naglasak, koji se gdjekada zove neoakutom, a katkada opet čakavskim akutom (sam ga je često nazivao i hrvatskim akutom), od novoštokavskoga dubokouzlaznoga (upravo "dubokoga uzlaznoga") naglaska, koji se obično zove dugouzlaznim, a koji se u štokavskome petonaglasju smjenjuje s visokouzlaznim. Za strogi opis toga naglaska vidi László 1996a:339. Usp. i sljedeći ulomak, gdje se opisuje "visokouzlazni napjevak": »Visokī se uzlaznī dugī jednoslogī napjevak... ozbiljāvā 'vīsom na kōncu, na_drugōj polovici, na_drugōme hīpu, kojega god d'uga jednosloga. Nēmā razd'iobenē ograničbē, jer se jāvljā na kojeme god sl'ogu u_izgovornōj cjelin'i« (isto, 337). Općenito se služim nazivljem što ga je rabio profesor László, no budući da ono nije u nas u cijelosti prihvaćeno, u ovome prilogu kadšto upozoravam na moguće razlike. 
vim udvajanjem, ali da ničim nije obilježeno mjesto naglaska, tj. mjesto siline (László: natiska), nije naime obilježeno koja je od tih dviju duljina doista naglašena). K tomu, nije posve jasno zašto bi zapis od lozee trebalo pročitati od lozêe, jer bi se očekivalo od lozẽ (prema primjeru muukee $=m \bar{u} k \tilde{e})$, a posve je neobična tvrdnja da i zapis od loze treba pročitati od lozê, jer u zapisu od loze nema ničega što bi na to upućivalo (naime nema uopće nikakve obilježenosti). Slično se može ustvrditi i za odčitani naglasak mejâš, jer bi se, i opet prema primjeru mūkẽ, očekivalo mejãš (drugo je pitanje što je ta visokouzlazna duljina u tome primjeru drugačije zapisana).

Napokon, $\mathrm{u}$ takvim se razmatranjima znade i pogriješiti. Naime, $\mathrm{u}$ Vrančićevu se petojezičnome rječniku ${ }^{6}$ zapis mukà ne navodi u latinskoj natuknici farina, kako kaže Putanec, nego u natuknici vexatio. To znači da za istu riječ imamo dva različita zapisa Múka i Mukà, jednom u natuknici labor, a drugi put $\mathrm{u}$ natuknici vexatio (dakle $\mathrm{u}$ istome ili $\mathrm{u}$ vrlo bliskome značenju). I upravo nam ta neujednačenost, neustaljenost zapisa kazuje da moramo biti oprezni (vrančićevski rečeno: da valja biti opreznu). A takvih primjera, kako će se vidjeti, u rječniku ima još dosta. Naprotiv, u natuknici farina nalazimo zapis Muuka, bez nadslovka, ali s udvojenim samoglasnikom $u$. Ako bismo u nominativu jednine te riječi pretpostavili naglasak mūkà ('brašno'), na temelju genitiva jednine mūkẽ (u mogućem sustavu čakavskoga, i ujedno starohrvatskoga tronaglasja), to bi značilo da je udvojenim samoglasnicima obilježena samo duljina, a ne i mjesto siline. No zapisano je samo mūke, a mjesto siline odčitali smo, ili ako se tako hoće - dodali smo mi sami (kao što je u muukee zapisano samo mūkē).

$\mathrm{K}$ tomu, nije dobro naveden ni zapis lanà, jer u latinskoj natuknici linteus nalazimo hrvatski prijevod Od Laná, dakle s oštrim znakom na prvome a zdesna, a ne s tupim znakom.

Mogao bi sada tkogod pomisliti da su naglasci mūkà, mūkẽ pogrješni, ili možda krivo odčitani, ali to naravno ne bi bila istina. Upravo su to naglas-

6 Vrančićev petojezični rječnik Dictionarium quinque nobilissimarum Europae linguarum, Latinae, Italicae, Germanicae, Dalmati[c]ae, E Ungaricae navodim prema pretisku iz 1992. Nakladnik ističe da je to 6. izdanje, brojeći pri tome ono od 1595. kao prvo. Preostala bi četiri izdanja bila redom ova: 2. izdanje - Petar Loderecker, Dictionarium septem diversarum linguarum, videlicet Latine, Italice, Dalmatice, Bohemicè, Polonicè, Germanicè, $\mathcal{E}$ Ungaricè, unà cum cuiuslibet linguae registro sive repertorio vernaculo, in quo candidus lector, sui idiomatis vocabulum, facile invenire poterit, E Typographaeo Ottmariano, Pragae, 1605. (o Lodereckerovu će rječniku još biti govora); 3. izdanje - József Thewrewk (tj. Török), Dictionarium pentaglottum, Typis Belnayanis, Posonii, 1834.; 4. izdanje - pretisak: Liber, Zagreb, 1971.; 5. izdanje - pretisak: The Bridge: A Journal of Croatian Literature, Collection of Croatian Literature, sv. 1., 1990., str. 199-234.

7 Sve Vrančićeve zapise hrvatskih riječi strogo poštujem, uključujući i razliku između velikoga i maloga slova. 
ci koji se očekuju, na temelju pretpostavke o tronaglasnome čakavskome sustavu koji je Vrančić kanio zapisati (a to jest pretpostavka od koje polazi Putanec). Slično je i s naglascima müka ('napor', 'trud'), lôv, pêt, bïti, pêst, lãn, lanä, sramotä, itd., s iznimkom onoga mejâ̌s i od lozê, koji su doduše mogući naglasci, ali u sustavu gdje bude mūkẽ, dakle u tronaglasnome sustavu, očekuje se mejãš i od lozẽ. Pitanje dakle nije jesu li to dobri naglasci, nego je li to ono što je Vrančić zapisao (ili htio zapisati). Takav nas pristup dovodi u neposrednu blizinu nečega što se u logici zove circulus vitiosus: ${ }^{8}$ istraživanje smo pokrenuli s nakanom da odgovorimo na pitanje na koji je način Vrančić rabio nadslovke te udvajanje samoglasnika i suglasnika, a sve to kako bismo dokučili koji je naglasni sustav namjeravao zapisati, no usuprot tomu - mi smo taj naglasni sustav pretpostavili i na osnovi njega započeli odgonetavati znakovlje, učitavajući pri tome ono što znamo neovisno o samome Vrančiću (to je taj "komparativni materijal"). Istraživanje bi se naime moralo držati samoga Vrančićeva rječnika, tj. samoga "korpusa" te pokušati razaznati značenje nadslovaka (kao i značenje udvajanja samoglasnika i suglasnika) tako reći - "iz sustava", a ne izvan njega, "iz okoline". To je dakle pristup koji bi - općenito govoreći, a ne samo kada je riječ o Vrančiću - valjalo promicati. Pokušaj pak da se na osnovi takva pristupa razmotri značenje nadslovaka u Vrančićevu rječniku, predmet je ovoga priloga.

\section{Raznolika poraba nadslovaka}

Ali da se vratimo na početak. Kao i mnogi drugi hrvatski pisci, posebice oni stariji, te osobito sastavljači rječnika i pisci slovnica, tako je i Faust Vrančić u svome petojezičnome rječniku pri zapisu hrvatskih riječi mjestimice rabio i nadslovke. Njihovo je bilježenje, grubo uzevši, uvjetovano željom da se riječ zapiše što "vjernije". U porabi su uglavnom bila tri znaka, naslijeđena iz tradicije grčkih gramatika, kojima se u grčkome označuju ova tri naglaska (Marotti 2013:I.12):





3. - zavinuti naglasak, tj. cirkumfleks ( $\pi \varepsilon \varrho \iota \sigma \pi \omega \mu \varepsilon ́ v \eta ~ \pi \varrho 0 \sigma \omega \delta i ́ \alpha)$.

Latinska je gramatička tradicija preuzela tri navedena znaka, premda ta trovrsnost nije bila potrebna da bi se zapisao naglasak $\mathrm{u}$ latinskome je-

8 Vidi o tome Marotti 2013:I.46-49. Usp. npr. sljedeći stavak: »može se naime dogoditi da se o značenju nadslovaka govori na temelju pretpostavljenoga naglasnoga sustava, a da se istodobno razmatra naglasni sustav na temelju pretpostavljenoga značenja nadslovaka «. 
ziku (a kako je vrijeme protjecalo, nije više trebala ni za zapis grčkoga naglašivanja). U naših se je pisaca posljednji znak redovito javljao $u$ jednoj svojoj inačici, tj. kao alograf, i to u obliku "krovića", naime ovako: ^ . Poraba tih triju znakova traje u Hrvatskoj kakvih 250 godina, recimo od Kašićeve slovnice Institutiones linguae Illyricae, objelodanjene 1604. pa sve do polovice devetnaestoga stoljeća, jer ih nalazimo primjerice još i u Ilirskoj slovnici Vjekoslava Babukića, objavljenoj 1854. (Babukić navedene znakove, te ujedno i same naglaske koji su njima obilježeni, zove oštrim, težkim i zavinjenim), ${ }^{9}$ te također u Slovnici Hèrvatskoj Antuna Mažuranića, izašloj godine 1859. Ali dakako, njihova je poraba potvrđena i prije Kašića, primjerice u Vrančića, a i poslije Mažuranića, jer se je navedenim trima znakovima u bilježenju novoštokavskoga četveronaglasja znao služiti i Bulcsú László. ${ }^{10}$

No spomenutim se nadslovcima nisu svi pisci služili na isti način, tj. nisu ih svi rabili u istome "značenju". To je neobično važna činjenica i pri ovakvu istraživanju bitno ju je osvijestiti na vrijeme, tj. prije negoli se pristupi razmatranju kojega god pisca, u ovome slučaju Vrančića i njegove porabe nadslovaka. Valja naime uvidjeti da u takvu istraživanju ne može biti nikakva "apriorizma", da se dakle ne može a priori znati što je kojemu piscu određeni znak doista značio.

Razmatrajući značenje nadslovaka u Vitezovićevu Lexiconu, da bih upozorio na to o kakvoj je raznolikosti riječ, bio sam odabrao šest hrvatskih pisaca koji su se u svojim djelima služili trima nadslovcima (ili jednim od triju). Riječ je o sljedećim djelima (Marotti 2013:I.25-39): Bartol Kašić, Institutionum linguae Illyricae libri duo 1604./2002; Ardelio Della Bella, Istruzioni grammaticali della lingua illirica 1728./2006; ${ }^{11}$ Petar Knežević, Pisme duhòvnè ràzlikè 1765; Šime Starčević, Nòvà ricsôslovica ilìricskà 1812./2002; Ignjat Alojzije Brlić, Grammatik der illirischen Sprache 1850; Vjekoslav Babukić, Ilirska slovnica 1854. Evo što se može zaključiti o raznolikoj porabi nadslovaka na osnovi tako odabranoga uzorka (navodim samo zaglavak, bez raščlambe i potanka izvoda) (Marotti 2013:I.38):

Tupim je znakom bilježeno sljedeće:

- naglašena kračina, tj. kratkosilazni naglasak (Kašić, Della Bella)

9 Babukić kaže ovako: »Znakovah, kojimi se naglasak bilježi imade tri: težki (accentus gravis); oštri (accentus acutus) i zavinjeni (accentus circumflexus)« (1854:30). A zavinjeni piše kao "krović", tj. `.

10 Profesor ih je László, u razgovoru, pa pomalo i u šali, običavao zvati "oštrac", "tupac" i "krović".

11 Slovnica objelodanjena godine 1728. ispred rječnika pod naslovom Dizionario Italiano, Latino, Illirico. 
- duljina neovisno o naglasku (Knežević)

- silazno naglašena duljina, tj. dugosilazni naglasak, i zanaglasna duljina (Starčević, Brlić)

- kratkosilazni i kratkouzlazni naglasak (Babukić).

Oštrim je znakom bilježeno sljedeće:

- silazno naglašena duljina, tj. dugosilazni naglasak (Kašić)

- silazno naglašena duljina, tj. dugosilazni naglasak, i zanaglasna duljina (Della Bella, Babukić)

- novoštokavski dugouzlazni naglasak (Starčević, gdjegdje Brlić)

- visokouzlazni naglasak i prednaglasna duljina (Brlić).

Zavinutim je znakom bilježeno sljedeće:

- visokouzlazni naglasak (Kašić, Della Bella)

- kratkouzlazni naglasak (Starčević)

- naglašena kračina, tj. kratkosilazni naglasak (Brlić)

- novoštokavski dugouzlazni naglasak (Babukić).

Valja se dakle složiti s onim što je svojedobno ustvrdio Šime Starčević (1812./2002:113): ${ }^{12} » K o l i k o$ kgnìgah iliricskih otvorìsh, toliko chesh varstah od nadslovàkah nájti, i viditi, da se nijedan skoro ní je toliko tarsio svakoj besidi svoj náravski glàs dati, koliko Otac Philipovich u knjigam $\mathrm{Na}$ uka Ka[r]stjanskoga, i Stulli u svojem Ricsôlovnìu, dali se ni oni svagdi ne slàxù shto u nadslovku, shto u istom glàsu«.

Ipak, budući da od nečega treba započeti, može se prihvatiti, ali samo kao "radna pretpostavka", ono što jest bivalo dosta često, da tupi znak označuje naglašenu kračinu (premda, kako smo vidjeli, ne u svakoga pisca), oštri naglašenu duljinu, a kadšto i nenaglašenu (primjerice onako kao u mađarskome ili u češkome), a slično i zavinuti, tj. da označuje naglašenu duljinu, ali katkada i nenaglašenu (posebice ako se pisac kojim se bavimo, oštrim nije služio).

Važno se pitanje međutim postavlja onda kada se rabe i oštri i zavinuti znak u stanovitome djelu istodobno, pitanje koje se može sročiti ovako: razlikuje li dotični pisac te "dvije duljine", ili spomenute znakove rabi promiscue? Dakako, već bi mogući iznalazak da jedan od tih znakova označuje naglašenu, a drugi nenaglašenu duljinu bio vrijedan, ali sa stajališta hrvatskoga jezika, koji poznaje još jednu oprjeku na tonemnoj razini, naime onu

12 Zanimljivo je da i Starčević, u slovnici koja je objavljena prije više od dvije stotine godina, rabi riječ nadslovak $\mathrm{u}$ istome značenju u kojoj se ta riječ rabi i u ovome prilogu. Usp. i Marotti 2013:I.38. 
po visini tona (László: napjevka), ključno je pitanje zapravo ovo: bilježi li spomenuti pisac razliku između silaznosti i uzlaznosti? K tomu, ukoliko tu razliku bilježi, ili ju nastoji zabilježiti, postavlja se ujedno i pitanje kojim znakom zapisuje silaznost, a kojim uzlaznost, jer ni u tome nije bilo jedinstva u naših pisaca. Napokon, želimo li u potpunosti proniknuti u naglasni sustav koji spomenuti pisac rabi i nastoji ga zabilježiti, valja razmotriti i o kojoj je uzlaznosti riječ (visokoj ili dubokoj).

Kada je pak posrijedi Vrančićev rječnik, treba uzeti u obzir i to da Vrančić rabi i udvajanje samoglasnika i udvajanje suglasnika. U tome je bilo veće suglasnosti među našim piscima, pa je udvojeni samoglasnik redovito značio duljinu toga samoglasnika (zapravo duljinu toga sloga), pri čem i dalje ostaje pitanje je li ta duljina naglašena ili nije, dočim je udvojeni suglasnik redovito označivao da je prethodni slog kratak i naglašen, a razmjerno je rijetko značio nenaglašenu kračinu. Takva udvajanja dakako nisu nadslovci, ali se u širem smislu mogu smatrati nekom vrstom obilježenosti, tj. nekom vrstom dodatne obavijesti koju može sadržavati inače neobilježeni zapis. Moglo bi se stoga ustvrditi da se obilježenost postiže na različite načine: nadslovcima, podslovcima, ${ }^{13}$ udvajanjem samoglasnika, udvajanjem suglasnika, itd.

Uzmemo li u obzir sve načine koje rabi Vrančić, dakle ukupno 5 “znakova" (3 nadslovka i 2 udvajanja), valja primijetiti da je to i više nego što je potrebno da bi se zapisao koji mu drago sustav unutar skupa svih hrvatskih (naravnih) sustava (László: unutar hrvatskoga sustavlja). Pitanje je samo kako se tim "znakovima" služi.

\section{Obilježene riječi u Vrančićevu rječniku}

U Vrančićevu se rječniku nalazi ukupno 971 riječ pojavnica koja je na neki način obilježena: bilo nadslovkom, bilo udvajanjem samoglasnika ili suglasnika. Budući da je 10 riječi obilježeno na dva načina, tj. dvama "znakovima", a jedna riječ štoviše i na tri načina, dakle trima "znakovima", u cjelovitu se popisu svih primjera nalazi 12 pojavnica više $(10+2)$, i to zato što se 10 riječi javlja dva puta (tj. na dvama različitim mjestima u popisu), a jedna dakle tri puta (tj. na trima mjestima). ${ }^{14}$ Evo tih primjera (11 riječi različnica):

- Bolijeè (u natuknici satius), jedanput zbog tupoga znaka, a drugi put zbog udvojenoga samoglasnika

\footnotetext{
13 Kao primjerice $u$ hebrejskome.

14 Taj popis svih primjera donosim u Dodatku.
} 
- Dáár (u natuknici munus), jedanput zbog oštroga znaka, drugi put zbog udvojenoga samoglasnika, a treći put zbog dvaju (istovjetnih) nadslovaka

- Hittàr (u natuknici ocyor), jedanput zbog tupoga znaka, a drugi put zbog udvojenoga suglasnika

- Kàrà (u natuknici controversia), jedanput zbog tupoga znaka, a drugi put zbog dvaju (istovjetnih) nadslovaka

- mukeè (u natuknici simila), jedanput zbog tupoga znaka, a drugi put zbog udvojenoga samoglasnika

- Oppekà (u natuknici later), jedanput zbog tupoga znaka, a drugi put zbog udvojenoga suglasnika

- Oppovijßt (u natuknici omen), jedanput zbog udvojenoga samoglasnika, a drugi put zbog udvojenoga suglasnika

- Peddeßeet (u natuknici quinquaginta), jedanput zbog udvojenoga samoglasnika, a drugi put zbog udvojenoga suglasnika

- Roffzà (u natuknici ros), jedanput zbog tupoga znaka, a drugi put zbog udvojenoga suglasnika

- Villè (u natuknici furca), jedanput zbog tupoga znaka, a drugi put zbog udvojenoga suglasnika

- Zvvir (u natuknici animal, animans), jedanput zbog tupoga znaka, a drugi put zbog udvojenoga suglasnika.

Prema tome, u popisu se zapravo nalaze 983 riječi pojavnice $(971+12)$, od čega 283 primjera s nadslovkom (223 s tupim znakom, 56 s oštrim znakom i 4 sa zavinutim znakom), 486 primjera s udvojenim samoglasnikom, 212 primjera s udvojenim suglasnikom te 2 primjera s dvama (istovjetnim) nadslovcima. Ono što je na prvi pogled neobično, jest omjer primjera s nadslovkom i primjera s nekim udvajanjem, tj. $283: 698$, gdje je potonjih više nego dvostruko više. Posebice iznenađuje to da su među primjerima s nekim nadslovkom svega 4 riječi različnice obilježene zavinutim znakom te da je samo 56 riječi različnica obilježeno oštrim znakom. No od tih je 56 riječi različnica njih 13 potvrđeno i u zapisu s tupim znakom. Evo tih primjera:

- akó (u natuknici sin 'Dà-akó-ne') i akò (u natuknici nisi ‘Neg-akò') te Akò (2 puta, u natuknicama num i si)

- Brafnó (u natuknici esca) i Brafnò (u natuknici viaticum)

- Csrivá (u natuknici intestina) i Csrivà (u natuknici exta)

- Dá (u natuknici ast) i Dà (8 puta, u natuknicama quod, sed, sedenim, 
sin 'Dà-akó-ne', tamen, ut, verò, verum) te dà (2 puta, u dvama dodatcima rječniku: IC i SA) ${ }^{15}$

- Dó (u natuknici adusque) i Dò (2 puta, u natuknicama tenus i usque)

- Ká (u natuknici ad) i Kà (u natuknici versus)

- Kotál (u natuknici cacabus) i Kotàl (u natuknici lebes)

- Moré (u natuknici aequor) i Morè (u natuknici mare)

- Múka (u natuknici labor) i Mukà (u natuknici vexatio, različit nadslovak na različitome mjestu)

- né (u natuknici ferè 'Malo-da né') i Nè (u natuknici ne) te nè (2 puta, u natuknicama quidni 'Zafto nè' i quin? 'Kako nè?')

- $\quad N u ́$ (u natuknici age) i Nù (u dodatku U)

- Skodá (u natuknici damnum) i Skodà (u natuknici intertrimen[t]um)

- Zponé (u natuknici compedes) i Sponè (u natuknici pedica, u nešto drugačijem zapisu).

Pri tome u primjerima Dá i Dà (dà), Dó i Dò, Ká i Kà, né i Nè (nè), Nú i Nù, premda je riječ o kolebanju, valja primijetiti da nijedan od dvaju nadslovaka nije uporabljen na prozodijskoj razini. Posrijedi je običaj preuzet iz (novovjekovnoga) latinskoga da se neke vrste riječi, kao što su prijedlozi i veznici, a u latinskome osobito prilozi, obilježe (obično) tupim znakom na posljednjem slogu. No u Vrančićevu se rječniku vidi kolebanje i u latinskim primjerima, npr. verò, ali certé. U latinskome takvo obilježavanje služi ponajviše tomu da bi se razlikovale vrste riječi, recimo prilog od glagola, npr. amarè 'gorko', 's gorčinom' od amare 'voljeti'. Može se reći da u takvim primjerima tupi znak (a i oštri u certé) znači zapravo 'prilog'.

No u Vrančićevu se rječniku vidi kolebanje i u zapisu duljine u mađarskome, pa bude npr. nyúl 'zec' (u natuknici lepus), dakle s oštrim znakom (kako je i danas), ali i hatàr 'granica' (u natuknici limes), gdje je duljina obilježena tupim znakom (danas határ), a bude katkada i poput primjera saaros 'blatan' (u natuknici limosus), gdje je pak duljina obilježena udvojenim samoglasnikom $a, \mathrm{tj}$. aa (danas sáros).

Ako bismo sada, na osnovi preostalih 8 primjera, pretpostavili da je recimo u zapisu Csrivà tupim znakom na posljednjem slogu obilježena naglašena kračina, da bi dakle to u današnjem zapisu bilo črivä, tada tomu proturječe zapisi akó i Múka, jer bi i njih valjalo odčitati s kratkosilaznim

15 Kada se primjeri javljaju u kojem od triju dodataka Vrančićevu rječniku, tada umjesto latinske natuknice navodim pokratu dotičnoga dodatka, i to: $U$ = Vocabula Dalmatica, quae Ungari sibi usurparunt, IC = Institutio Christiana, SA = Symbolum apostolorum. 
naglaskom, tj. akồ ${ }^{16}$ i mùka, što opet znači da je u tim primjerima naglašena kračina obilježena oštrim znakom (osim naravno što zapisu Csrivà proturječi i zapis Csrivá). U zapisima Brafnó i Brafnò, Moré i Morè, Skodá i Skodà te Zponé i Sponè, neovisno o kojem je nadslovku riječ, ne očekuje se da je silina na tome mjestu, tj. ne očekuje se da bi bio naglašen posljednji slog (trebalo bi naime biti bräšno, möre (ili môre), škôda i spöne). Napokon, ako bismo u zapisu Kotál i odčitali kotãl, tj. da je oštrim znakom obilježena visokouzlazna duljina, tomu bi proturječili već navedeni primjeri akó, Múka i Csrivá.

U načelu, i to bi bilo dovoljno da se izvede zaključak kako značenje nadslovaka u Vrančićevu rječniku nije moguće utvrditi. Štoviše, za takav bi zaključak bio dovoljan i samo jedan protuprimjer onomu što smo pretpostavili, osim ako se za taj protuprimjer, s vrlo čvrstim razlogom, ne bi moglo ustvrditi da je posrijedi propust, omaha, ili štogod slično. Proturječja međutim ima još, i to dosta. Tako bi u primjerima Dobrotá (u natuknici bonitas), Kúp (u natuknici acervus), genitiv jednine Laná (u natuknici linteus 'Od Laná'), Mís (u natuknici mus), Peró (u natuknici penna) i Potóp (u natuknici diluvium) oštrim znakom bila obilježena naglašena kračina (u današnjem zapisu dobrotä, kùp, lanä, mìš, perồ i potöp), u primjeru Lóv (u natuknici venatio) silazna duljina (u današnjem zapisu lôv), u primjeru Móy (u natuknici meus) visokouzlazna duljina (u današnjem zapisu mõj), dočim bi u primjerima Grudá (u natuknici gleba) i Verá (u natuknici fides) oštrim znakom bio obilježen pogrješan slog, tj. posljednji umjesto pretposljednjega, jer se očekuje (u današnjem zapisu) grüda i vêra (dakle recimo Grúda i Véra). Sve to dakako na pretpostavci čakavskoga tronaglasnoga sustava.

S druge strane, u primjerima bi Bogàth (u natuknici dives), Diczà (u natuknici liberi), Dìnya (u dodatku U), Dnò (u natuknici fundum), Maglà (u natuknici nebula), Nogà (u natuknici tibia pedis) i Telè (u natuknici vitulus) tupim znakom bila obilježena naglašena kračina (u današnjem zapisu bogàt, dicä, dìnja, dnö, maglä, nogà i telë), u primjerima Krìv (u natuknici limus) i Sztàn (u natuknici domicilium) silazna duljina (u današnjem zapisu krîv i stân), u primjerima lozè (u natuknici palmes 'Prut-od lozè') i Meàs (u natuknici limes) visokouzlazna duljina (u današnjem zapisu lozẽ i mejãš), dočim bi u primjerima Koxà (u natuknici pellis), Malò (u natuknici paulum) i Ranà (u natuknici vulnus) tupim znakom bio obilježen pogrješan slog, tj. posljednji umjesto pretposljednjega, jer se očekuje (u današnjem zapisu) kôža, mälo i ràna (dakle recimo Kòxa, Màlo i Ràna). Sve to i opet na pretpostavci čakavskoga tronaglasnoga sustava.

16 Novoštokavski je naglasak àko, premda se danas uglavnom propisuje kao "standardan" naglasni lik äko. 
K svemu tomu valja dodati i (jedina) četiri primjera sa zavinutim znakom: Karâ (u natuknici iurgium), Lûgh (u natuknici cinis), Szvitâ (u natuknici stola) i Szvitâk (u natuknici cicindela). U zapisu bi Karâ zavinutim znakom bila obilježena naglašena kračina (u današnjem zapisu karä, zapravo kārä), u zapisu bi Szvitâ bio obilježen pogrješan slog, tj. posljednji umjesto pretposljednjega, jer se očekuje (u današnjem zapisu) svìta, dočim bi u zapisima Lûgh i Szvitâk zavinutim znakom bila obilježena visokouzlazna duljina (u današnjem zapisu lũg i svitãk). ${ }^{17}$ Osobito je važan zapis $L \hat{u} g h$, koji bi mogao biti potvrda da je Vrančić zavinutim znakom bilježio visokouzlaznu duljinu, jer je to jedna od onih dragocjenih riječi u ovakvim istraživanjima. Dragocjenost riječi lüg, koja znači 'pepeo', sastoji se u tome što se ona u nominativu jednine razlikuje samo (visokom) uzlaznom duljinom od riječi lûg, koja znači 'gaj', a ima silaznu duljinu. Na taj se način na tonemnoj razini može uspostaviti oprjeka uzlaznost : silaznost, tj. lũg : lûg, i to je ujedno najmanja razlika među tim dvjema riječima (bolje bi bilo reći dvjema postavama), promjena koje uvjetuje istodobno i promjenu značenja. Tako je i s parom sũd 'prosuda', 'sudište' : sûd 'posuda'.

Te se riječi u današnjem knjževnome jeziku u nominativu jednine ne razlikuju po naglasku: sve četiri naime u spomenutome padežu imaju dugosilazni naglasak, tj. u današnjem zapisu lûg, lûg, sûd, sûd. U genitivu se jednine međutim pojedini parovi razlikuju, jer se u dvjema od navedenih riječi dugosilazni "održava”, tj. bude lûga i sûda (naime 'gaja' i 'posude'), a u dvjema se mijenja u dugouzlazni, tj. bude lúga i súda (naime 'pepela' i 'prosude', 'sudišta'). Ovi potonji primjeri pokazuju da njihov dugosilazni naglasak iz nominativa jednine nije izvoran, nego da je naknadno izjednačen s izvornim dugosilaznim, kakav nalazimo u dvama prethodnim primjerima. S druge strane, prije novoštokavskoga pomaka siline za jedan slog ulijevo u tih je imenica genitiv jednine bio lügà, südà. Prema tome, u književnome je jeziku lûg, lúga i sûd, súda, u tronaglasju (čakavskome, ali također u štokavskome) lüg, lūgà i sũd, sūdä, a u štokavskome je petonaglasju, naime u sustavu najveće naglasne raznolikosti, lũg, lúga i sũd, súda, gdje se u sklonidbi tih riječi smjenjuju dvije uzlaznosti, visoka (stara hrvatska) i duboka (novoštokavska), što je velika rijetkost.

Od tih (i sličnih) parova oprjeka treba zapravo i započeti ovakva istraživanja, no upravo ih ne nalazimo u Vrančićevu rječniku. Vrančić riječ lũg navodi tri puta, jedanput u navedenome zapisu Lûgh, drugi put u zapisu

17 Za naglaske poput svitãk vidi Hraste 1959:8, kao i Moguš 1966:67. Za razdiobu: kračina : silazna duljina : visokouzlazna duljina u takvim primjerima vidi Lisac 2009:117-118. 
Luugh (u natuknici lixivium), a treći put u zapisu Lug (u dodatku U), ${ }^{18}$ dočim riječ lûg navodi šest puta, i to tri puta u zapisu Luugh (u natuknicama lucus, ${ }^{19}$ saltus i sylva), dva puta u zapisu Luug (u natuknici nemus i u dodat$\mathrm{ku} \mathrm{U}$ ), ${ }^{20}$ te jednom u genitivu jednine u zapisu Od-Luga (u natuknici sylvestris). Prema tome, izuzmemo li zapis L $\hat{u} g h$, te dva neobilježena zapisa (Lug i Od-Luga), preostaje nam šest zapisa s udvojenim suglasnikom $u, t j$. $u u$ (dočetno se $h$ ovdje može zanemariti), gdje je obilježena duljina, ali nije ujedno i uzlaznost ili silaznost. To znači da - poredamo li tih šest zapisa ovako: Luugh, Luugh, Luugh, Luugh, Luug, Luug - nije moguće odgovoriti kojemu zapisu, ili kojemu liku, pripada koje značenje, a da pri tome ne (po)gledamo latinski, talijanski, njemački ili mađarski prijevod. Dakle, to nije moguće učiniti samo na osnovi zapisa.

Usporedbe radi, za razliku od Vrančićeva rječnika, u Vitezovićevu rječniku to jest moguće učiniti, i to samo na osnovi zapisa. Vitezović te dvije riječi razlikuje u zapisu ovako: lúg 'pepeo' i lûg 'gaj' (dakle oštrim znakom bilježi visokouzlaznu duljinu, taj tzv. čakavski ili hrvatski akut, a zavinutim znakom silaznu duljinu, tj. dugosilazni naglasak). Tu razliku provodi dosljedno, jer se zapis lúg javlja na osam mjesta u njegovu rječniku svagda $\mathrm{u}$ istome značenju u natuknicama cinefacere, ciner, cinflare, cinis, lix, lixivia (dva puta) i India (u četvrtome dodatku), dočim se zapis lûg nalazi na dvama mjestima, također $\mathrm{u}$ istome značenju (u natuknicama nemus i saltus $\left.{ }^{2}\right){ }^{21}$ I to je ta bitna razlika.

Dosljednost u zapisu neobično je važna, jer svjedoči o njegovoj ustaljenosti, pokazujući da poraba pojedinoga nadslovka nije "slučajna", ili "proizvoljna", nego da se određeni nadslovak bilježi svjesno i s posve određenom namjerom. Primjerice, zapis vodà, gdje je tupim znakom obilježena naglašena kračina, tj. kratkosilazni naglasak (dakle $u$ današnjem zapisu vodä), javlja se 24 puta u Vitezovićevu Lexiconu, i to svagda samo u takvu zapisu: u natuknicama aqua, aqua eximia (pod aqua, 2 puta), aqua fluvialis (pod aqua), aqua fontana. aqua sacra (pod aqua), aqua jugis (pod aqua), aqua languida. stagnum (pod aqua), aqua nivalis (pod aqua), aqua palustris (pod aqua, 2 puta), aqua puteana. aqua putealis (pod aqua), aqua salsa. aquæ marinæ

18 To je dodatak u kojem Vrančić donosi riječi koje su, po njegovu mišljenju, Mađari posudili od Hrvata. Zanimljivo je da u tome popisu riječ Lug navodi mađarski kao Luug (danas lúg).

19 Tu je zapis zapravo Lü̈gh, ali to će biti tiskarska pogrješka. Osim nje u toj natuknici ima i hrvatsku otpovjednicu Gay (kao i u natuknici nemus).

20 Na tome mjestu ima dakle zapis Luug, a u mađarskome navodi Lugas.

21 Raspravljajući o značenju nadslovaka u Vitezovićevu Lexiconu, upozorio sam na 30 takvih parova oprjeka (premda ih ima znatno više). Vidi Marotti 2013:I.208229. 
(pod aqua), aqua stativa (pod aqua), cataracta $^{1}$, fervet aqua (pod fervere), guttus. gutturnium (pod guttus), humilis aqua (pod humilis), lympha, nilli, paracentesis, siphon, stacte, stativæ, stranguria, dočim se genitiv jednine iste imenice, u Vitezovićevu zapisu vodé, gdje je oštrim znakom obilježena visokouzlazna duljina, tj. čakavski akut (dakle u današnjem zapisu vodê), javlja 13 puta u istovjetnu zapisu: agoga, alluvio, crepido, deficit aqua (pod deficere), exundatio, haustus aquæ, vini (pod haustus ${ }^{2}, 2$ puta), hydria, hydrophòbus, malabathrum, haurire a $\langle u\rangle q u a m$ (tj. aquam) de puteo (pod puteus, 2 puta), remulcare (Marotti 2013:I.252). ${ }^{22}$

A slično je i s parom sũd i sûd. Riječ sũd Vrančić navodi četiri puta, i to tri puta u zapisu Szuud (u natuknicama arbitrium, existimatio i opinio), a jedanput u zapisu Szud (u natuknici iuditium), dočim riječ sûd navodi jedanput, i to u zapisu Szuud (u natuknici vas). I tu je vidljivo da nam, izuzmemo li jedan neobilježeni zapis $(S z u d)$, preostaju četiri zapisa s udvojenim suglasnikom $u$, tj. $u$, gdje je obilježena duljina, ali nije ujedno i uzlaznost ili silaznost. I opet se može reći da, poredamo li ta četiri zapisa ovako: Szuud, Szuud, Szuud, Szuud, nije moguće odgovoriti kojemu zapisu, ili kojemu liku, pripada koje značenje, a da pri tome ne (po)gledamo latinski, talijanski, njemački ili mađarski prijevod. (Vitezović dakako te riječi razlikuje ovako: fúd 'prosuda', 'sudište' i fûd 'posuda'; f je Vitezovićev zapis za /s/.) Stoga valja zaključiti da Vrančić udvajanjem samoglasnika zapisuje samo duljinu.

Možda bismo, u donekle "sofisticiranijem" pristupu, mogli reći da se u Vrančićevu rječniku ipak može naći kakva druga oprjeka, poput oprjeke duljina : kračina. Jer, zapis Luuk (u natuknici arcus) stoji u oprjeci sa zapisom Luk (tri puta: u natuknicama allium 'Luk cseßni', bulbus i caepe 'Luk clerlyeni'). Istina, zapis Luk ničim nije obilježen (recimo Lùk ili Lukk), ali bi se moglo ustvrditi da je kračina obilježena upravo time što uopće nije obilježena (obilježenost neobilježenošću), ili pak time što nije obilježena duljina. To znači da pod pretpostavkom dosljedno bilježene duljine, kračinu ne treba (dodatno) obilježavati, jer je obilježena upravo izostankom biljega duljine. Da, samo kako smo vidjeli, Vrančić duljinu ne bilježi dosljedno, tj. posvuda gdje je to potrebno.

Osim parova riječi koje stoje $\mathrm{u}$ oprjeci te ustaljenoga zapisa što veće čestote, od iznimne su važnosti i oni primjeri koji su obilježeni dva-

22 U spomenutoj raspravi navodim sve one riječi koje se u Vitezovićevu rječniku javljaju u istovjetnu zapisu 5 ili više puta (pod uvjetom da se nadslovak rabi na prozodijskoj razini). Vidi Marotti 2013:I.230-254. U prelomljenim se zagradama navode suvišna slova, kojih katkada bude kako u Vitezovićevu, tako i u Vrančićevu zapisu (tj. kako u Vitezovićevu rukopisu, tako i u Vrančićevu objavljenome rječniku). 
ma nadslovcima, posebice dvama različitim nadslovcima. U Vrančićevu se rječniku nalaze samo dva takva primjera i to obilježena istovjetnim nadslovcima: Dáár (u natuknici munus) i Kàrà (u natuknici controversia). Zapis Kàrà djeluje kao proturječan sam u sebi, jer se čini kao da riječ ima dva naglaska, recimo (u današnjem zapisu) kärä, ako bismo pretpostavili da je tupim znakom obilježena naglašena kračina. Druga bi bila mogućnost da se kaže da tupi znak na prvome $a$ slijeva, u takvoj okolini, označuje prednaglasnu duljinu pa bi stoga bilo kārä (novoštokavski je kára), ali to bi bio jedini takav slučaj. No posrijedi će dakako biti tiskarska pogrješka, jer se u Vrančićevu rječniku ta riječ nalazi još na 5 mjesta, i to u trima različitim zapisima: Kara (u natuknici contentio), Kara (u natuknici disceptatio), Karâ (u natuknici iurgium), Karà (u natuknici lis) i Karà (u natuknici rixa). Ukupno je dakle ta riječ zapisana 6 puta na 4 različita načina.

U primjeru pak Dáár udvojenim bi samoglasnikom $a$, tj. aa, bila obilježena duljina, a oštrim znakom silaznost, dakle kao u primjeru Lóv. Pri tome međutim taj znak ne bi trebalo ponavljati. Dovoljno bi bilo ovako: Dáar, gdje bi - pod pretpostavkom da (jednu) duljinu shvatimo kao dvije kračine, tj. kao dvije more (László: dva hipa) - nadslovak (u ovome slučaju oštri znak) upozoravao da su visina (i ujedno silina) na toj prvoj mori te da je posrijedi silaznost. Suprotno bi bilo recimo u mogućem zapisu Luúg 'pepeo', gdje bi nadslovak upozoravao da je visina na drugoj mori te da je posrijedi (visoka) uzlaznost. Tako bi se mogao tumačiti i primjer mukeè, samo što bi druga mora, tj. drugi e bio obilježen tupim, a ne oštrim znakom. No tomu proturječi primjer Bolijeè, jer se očekuje bölje (ili böljē) a ne boljẽ, što opet govori o tome da su oba zapisa, i mukeè i Bolijeè (a zacijelo i Dáár), zapravo tiskarske pogrješke. Slično se može reći i za zapise Hittàr (jer to bi bilo hìtär), Oppekà (öpekä), Roffzà (rösä) i Villè (vìlê), a zacijelo i za zapis Zvvir, gdje će vv biti $w$. Preostale dvije od spomenutih 11 riječi različnica koje su obilježene dvostruko ili trostruko, ne moraju se smatrati tiskarskim pogrješkama. Primjer se naime Oppovijßt može odčitati kao òpovīst, gdje bi udvojenim suglasnikom bila obilježena naglašena kračina, a udvojenim samoglasnikom duljina posljednjega sloga (jer je $i j=i i)$, dočim bi u primjeru Peddeßeet udvojenim samoglasnikom bila obilježena duljina posljednjega sloga, a udvojeni je suglasnik samo posljedak tvorbenoga, ili "polutvorbenoga" pravopisa, gdje je zapisana prilagodba po zvučnosti, ali su ostala oba $d$, bez "gubitka" prvoga od njih (u tvorbenome bi bilo Petdeßeet).

Stoga se valja složiti s onim što kaže Marko Samardžija (2005:67): »Pravu ortoepsku vrijednost tih nadslovaka nije, međutim, moguće jednoznačno >dešifrirati «. Drugo je pitanje kako tu činjenicu treba tumačiti. 


\section{Udvajanja}

Preostalo bi dakle udvajanje samoglasnika i udvajanje suglasnika. Udvajanjem samoglasnika označuje se, vidjeli smo već, duljina, a udvajanjem suglasnika, makar u načelu, naglašena kračina prethodnoga sloga. No udvojenost je suglasnika uvjetovana katkada i tvorbenim pravopisom, npr. Bezzakonye (u natuknici iniuria), ili pak već spomenuti primjer Peddeßeet, a katkada opet pukom tiskarskom pogrješkom, npr. Doyitt (u natuknici lactare), Drobnno (u natuknici minutim), Ppribigal (u natuknici perfuga), ili

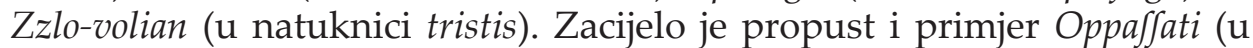
natuknici cingere), gdje izgleda kao da su udvojena dva različita suglasnika (to bi značilo da su posrijedi dva udvajanja suglasnika u istoj riječi), no zapis $\iint$ stoji pogrješno umjesto $\beta$, što je, uza $s z$ i $\int z$, redovit Vrančićev zapis za /s/, dočim je $\iint$, koje bude katkada i samo $\int$, redovit Vrančićev zapis $\mathrm{za} / \check{s} /$. Štoviše, zapis bi se $\iint$ mogao odčitati i kao udvojeno š, tj. šš, što očevidno nije posrijedi, a da je tako vidi se i iz latinske natuknice cinctus, gdje se nalazi hrvatska otpovjednica Oppaßan (očekivalo bi se dakle Oppaßati za cingere). Posebno je pitanje kako treba shvatiti udvojeno $v$, tj. vv, kao u primjeru Mlohavv (u natuknicama debilis i languidus), ili Czelovv (u natuknicama basium i suavium), jer se ni u jednome od tih dvaju primjera ne očekuje da bi bio naglašen posljednji slog, nego pretposljednji, dakle (u današnjem zapisu) mlöhav i cjēlōv. Također se ni u riječi Czivv (u natuknici canna) ne očekuje kračina samoglasnika $i$, nego upravo njegova duljina (kako se vidi iz zapisa Cziiv u natuknici tubus). A kako tumačiti zapise Dvvoyczi (u natuknici gemellus), Vvran (u natuknici ater), Vvridnofzt (u natuknici valor), Vvriti (u natuknici aestuare), Vvruch (u natuknici fervidus) i Vvruchina (u natuknici aestus), ili pak već spomenuti primjer Zvvìr? Zapravo, pitanje je može li se zapis $v v$ uopće smatrati udvojenim suglasnikom, ili je samo riječ o inačici pismena $w$. Potonjemu bi u prilog govorile i neke njemačke riječi, gdje umjesto $w$ nalazimo $v v$, npr. Fußvveg (u natuknici trames), Vvinden (u natuknici torquere), Vveite (u natuknici tractus), itd.

Ipak, u Dodatku ovomu prilogu, u popisu svih riječi koje su u Vrančićevu rječniku (nekako) obilježene, navodim i primjere s udvojenim $v$, tj. vv, pače i sve primjere gdje je udvojeni suglasnik posljedica tiskarske pogrješke (poput Ppribigal). No takvih je zapisa znatan broj, i kada bi se oni uklonili, broj riječi s udvojenim suglasnikom bio bi uvelike smanjen. To nas pak dovodi do uvida da je ono čega uistinu ima dosta, i što je provedeno bez većih propusta (ima ih svega nekoliko, poput lika Bolijeè), isključivo udvajanje samoglasnika. No u predgovoru svomu rječniku, pod naslovom Author Benigno Lectori Salutem - govoreći o slovopisu pa donekle i o pravopisu 
— »dobrohotnomu čitatelju « upravo tako kaže i sam Vrančić: ${ }^{23}$ »Vocales longas, ut cognofcantur, plerumque duplicauimus...« Nigdje nema ni riječi o udvajanju suglasnika, niti se igdje spominju nadslovci. Potonji se međutim spominju u dodatku pod naslovom De ratione legendi, što ga je Vrančić priložio djelu Xivvot nikoliko izabraniih divviicz godine 1606. Ondje se kaže ovako (Vrančić 1606./1995:116):

»Vt Vocalium qvantitatem, \& aliqvarum Confonantium litterarum fonum expri〈pri>meremus: noluimus eos imitari, qvi more Græcorum lineolis, vel Hebræorum, qvi punctis utuntur. Nam hæ lineæ, \& puncta facilius immutantur, vel eliduntur, quàm à plerifqve intelliguntur. Commodius vifum est, eas duplicare, nempe fic: Aa, ee, ij, oo, uu. Hæ vocales designant fillabas longas, ficut apud antiqvos, teste Fabio.«

Dakle, kako sam navodi, Vrančić se ne želi služiti crticama (lineolis), poput Grka (to su ona tri znaka, tj. tri nadslovka, kojima se u grčkome označuju tri naglaska), ni piknjama (punctis), iliti točkama, poput Hebreja (to su podslovci u hebrejskome), i to zato što se te crte i piknje (hæ lineæ, $\mathcal{E}$ puncta) lakše zamjenjuju (immutantur), ili se (štoviše posve) izostavljaju (eliduntur), lakše dakle nego što ih većina razumije (bolje reći - uspije razumjeti). Latinski glagol immutare znači 'promijeniti', 'zamijeniti', ali u lošem smislu. To bi značilo da se te crte (tj. nadslovci) uzajamno zamjenjuju i time se ujedno kvare, iskrivljuju. Zapravo, ne "iskrivljuje" se sam lik tih znakova (crta, òznačnīk, signifiant), nego njihovo značenje (označènīk, signifié) pa se stoga više ne zna koji što znači. Jednostavno rečeno: prije će se dogoditi da se ti znakovi u tisku uzajamno zamijene, nego što će čitatelj moći razumjeti što koji od njih znači. A to je, kako je prethodna raščlamba pokazala, upravo ono što se je i dogodilo u Vrančićevu rječniku (ili - ako se tako hoće - Vrančićevu rječniku).

Usuprot tomu, zgodnije je (commodius), veli Vrančić, udvostručiti (duplicare), ili udvojiti samoglasnike. Vrančić pri tome, kao i u predgovoru rječniku, izrijekom kaže da ti (udvojeni) samoglasnici označuju (samo) duge slogove (hæ vocales designant fillabas longas), te se u vezi s time pozivlje na Marka Fabija Kvintilijana (Marcus Fabius Quintilianus). Oni dakle označuju duljinu, i - moglo bi se dodati - samo duljinu.

A tako uglavnom i jest u djelu Xivvot nikoliko izabraniih divviicz (Vrančić 1606./1995). Što se tiče nadslovaka, oštri se i zavinuti znak ne rabe, nego

23 Taj predgovor obaseže 2 stranice, prije njega dolazi posveta (2 stranice), a poslije njega pohvalna pjesma (2 stranice). Te stranice nisu obrojene. Prije posvete nalazi se naslovnica i jedna prazna stranica. Imali bismo dakle $2+2+2+2$, tj. 8 (neobrojenih) stranica. Računamo li naslovnicu kao prvu stranicu, predgovor bi bio na str. 5-6, a sam navodak na str. 6. 
samo tupi, a i taj razmjerno rijetko, te najčešće na neprozodijskoj razini, kao u primjerima pò Proroku, ù tamniczu, à dà nikor, pò yiednoyi, ${ }^{24}$ gdje su dakle tupim znakom obilježeni prijedlozi i veznici. Ima primjera gdje se čini da se tupi znak rabi na prozodijskoj razini te da je njime obilježena naglašena kračina (dakle kratkosilazni naglasak), primjerice stò onà, na pràg, $z a z l o{ }^{25}$ ali tomu opet proturječe primjeri poput dàr, ${ }^{26}$ uz češći zapis daar, ${ }^{27}$ gdje izgleda kao da je tupim znakom obilježena silazna duljina (dakle dugosilazni naglasak), ili pak primjeri poput tù ludoozt, ili Tò reksi, ${ }^{28}$ koji inače budu pisani udvojenim samoglasnikom, npr. i tuu, ili Csuyuchi too. ${ }^{29} \mathrm{~A}$ ima i posve netočnih zapisa, gdje je posrijedi vjerojatno tiskarska pogrješka, poput dayuchi Bogù, Virù, fzlavèe, i sl. ${ }^{30}$

Nađe se i riječi pisanih s udvojenim suglasnikom, poput paddofe ili uffanya $^{31}$ gdje bi udvojenim suglasnicima bila obilježena naglašena kračina prethodnoga sloga. No ni tih primjera nema previše (premda se dva nalaze u samome naslovu). $\mathrm{K}$ tomu, kada su posrijedi takvi zapisi, valja dodatno biti oprezan, jer udvojeni suglasnik može biti posljedica tvorbenoga pravopisa, kao u primjeru yiztinno, ${ }^{32}$ što je prilog od pridjeva istinan, istinna, istinno (dakako, $\mathrm{u}$ tvorbenome zapisu). Zanimljiv je primjer divoiicz, iz naslova, jer bi se moglo smatrati da je tu udvojenim suglasnikom obilježena kračina prethodnoga sloga, a udvojenim samoglasnikom (zanaglasna) duljina u tome genitivu množine, dakle $u$ današnjem zapisu dìvic (sve pod uvjetom da vv odčitavamo kao udvojeni suglasnik). Utoliko bi taj primjer zorno pokazivao da je moguće rabiti dvije (pa i više) "obilježenosti", da ne kažem dva "znaka", u ovome slučaju udvajanje suglasnika i udvajanje samoglasnika, pri zapisu određene riječi. No s druge strane, zapis xivvot, također iz naslova, govorio bi suprotno, naime da vv ne bi trebalo odčitavati kao udvojeni suglasnik, nego kao $w$, jer neće zacijelo biti život (a još manje žìvot). U nenovoštokavskim se naime govorima očekuje živöt pa bi zapis trebao biti xivott, ili pak xivòt, pod uvjetom da se tupim znakom obilježava kratkosilazni naglasak. Vrančić u rječniku ima Xiuot (u

\footnotetext{
24 Isto, (redom) str. 8, str. 12, str. 12, str. 13 (Xivvot S. Katarinee).

25 Isto, (redom) str. 7, str. 11 (Xivvot S. Katarinee), str. 112-113 (Xivvot S. Barbaree, iz Damafcena, i Arfenia).

26 Isto, str. 7 (Xivvot S. Katarinee).

27 Isto, npr. str. 29 (Xivvot S. Czeczilie).

28 Isto, (redom) str. 7, str. 8 (Xivvot S. Katarinee).

29 Isto, (redom) str. 11, str. 12 (Xivvot S. Katarinee).

30 Isto, (redom) str. 10 (Xivvot S. Katarinee), str. 52, str. 61 (Xivvot S. Febroniee po
} Thomaidi koludriczi pijfzan).

31 Isto, (redom) str. 11, str. 11 (Xivvot S. Katarinee).

32 Isto, str. 9 (Xivvot S. Katarinee). 
natuknici vita, uz otpovjednicu Xitak) te xivot (u dodatku SA), dakle oba puta neobilježeno.

Redovito međutim bude ovako: ${ }^{33}$ „Csuyuchi too Czelzaar nyee fzpametnoo govorenye, i videchi nyee veliku lipoofzt, csinyase mulze da z'komgodi Boxiczoom govorij.« Pri tome je udvojenim samoglasnicima obilježena samo duljina, što ne znači da je ta duljina ujedno i naglašena, jer ona može biti i prednaglasna (npr. xiitak, tj. žîtäk) ${ }^{34}$ i zanaglasna (npr. plameen, tj. plämēn), ${ }^{35}$ a ako i jest naglašena, iz samoga se zapisa ne može pretkazati o kojem je upravo naglasku riječ, dugosilaznome ili visokouzlaznome (npr. Jzveeti Duuh valja odčitati kao svẽt $\bar{L}$ Dûh, ${ }^{36}$ zapise graada i fztaan kao grâda i stân, a zapise Dvoor i fzuud kao Dvõr i sũd). ${ }^{37}$ Kažem, ne može se pretkazati iz samoga zapisa, što opet ne znači da naglasak uopće nije moguće rekonstruirati, tako reći iz "okoline", tj. oslanjajući se na građu iz naših narječja, dakle na osnovi onoga što i inače znamo o pretpostavljenome naglasnome sustavu. ${ }^{38}$ I ovdje navedeni primjeri svẽtī Dûh, grâda, stân, Dvõr i sũd zapravo su rekonstruirani, jer uistinu piše ovo: svēti Dūh, grāda, stān, Dvōr i sūd.

Uočiti je usput Vrančićev pismènī lik Duuh, koji se javlja na više mjesta u Xivvotu nikoliko izabraniih divviicz pa i u padežu, primjerice u akuzativu jednine Duuha (»pofzlal naam Izvetoga Duuha«), ${ }^{39}$ a nalazi se i u rječniku (u natuknici spiritus)..$^{40}$ Takav bi se zapis slagao s onim kako je u Senju (Moguš 2002:25) i na Vrgadi (Jurišić 1973:51), naime dûh, dûha, a ne düh, dùha, kako ima Vuk Stefanović Karadžić u drugome izdanju svoga Srpskoga rječnika (za düh, dùha navodi »der Geist, spiritus«, dočim za dûh veli »der Hauch, spiritus«) (1852:146), a za njim onda Broz i Iveković u Rječniku hrvatskoga jezika (gdje je provedena istovjetna naglasna razlika u vezi sa značenjem) (1901:I.272) te kako se danas uglavnom i propisuje (Šonje 2000:219). ${ }^{41}$ Usuprot tomu, u Akademijinu je rječniku Petar Budmani,

\footnotetext{
33 Isto, str. 8 (Xivoot S. Katarinee).

34 Isto, str. 25 (Xivvot S. Czecziliee).

35 Isto, str. 46 (Xivvot S. Agathee).

36 Isto, str. 80 (Xivvot S. Eugenie).

37 Isto, (redom) str. 17, str. 17 (Xivvot S. Czecziliee), str. 8 (Xivvot S. Katarinee), str. 6 (Xivvot S. Tekle).

38 To je za određeni broj primjera iz djela Xivvot nikoliko izabraniih divviicz učinio Josip Lisac 1995:153-154 i 2004:29-30.

39 Vidi Faust Vrančić, Xivvot nikoliko izabraniih divviicz, str. 10 (Xivvot S. Katarinee).

40 U rječniku se javlja još dva puta, i to u dodatku SA, ali bez udvojenoga samoglasnika, tj. od Duha ì ù duha.

41 Također Klaić 2013:16. Klaić veli da je naglasak te imenice düh, dùha, dakle pre-
} 
koji je obrađivao slovo $D$, obilježio naglasak dûh, dûha, te je obje (tj. »obje«) spomenute riječi obradio zajedno, $u$ jednoj te istoj natuknici. Prema tome, iako je Budmani bio vukovac, $u$ tome ipak nije slijedio Vuka (kao ni inače kada je bio u pitanju naglasak). Budmani veli ovako: ${ }^{42}$ »Akc. kaki je ovdje biḷežen taki je bio od starina... i taki je još u Dubrovniku; ...u Vukovu rječniku ima i drukčije biḷežen akc.: düh, dùha...; po svoj je prilici ovaj akc. postao kod onoga dijela našega naroda koji ne izgovara $h$, te se $u$ pred drugijem vokalima (n. p. dua, duu itd.) skratilo (isporedi prah). «I doista, u prvome izdanju Vukova rječnika, objavljenome 1818., kada Vuk još nije znao za $h$, nalazimo ovako: $\partial \grave{y}$, dya (poznato je da Vuk tada još nije razlikovao ni kratkosilazni i kratkouzlazni naglasak). ${ }^{43}$

Takvih bi se zanimljivih primjera u Vrančićevu rječniku našlo još podosta. Ali da se vratimo na udvajanje samoglasnika. To je dakle ono što je u Xivvotu nikoliko izabraniih divviicz Vrančić redovito (i posve svjesno) rabio. Uzme li se u obzir svih pet spomenutih načina dodatnoga obilježavanja riječi, samo se za udvajanje samoglasnika može ustvrditi da se u Xivvotu sigurno rabi, tj. da je takva poraba u Xivvotu doista ustaljena. Kako međutim razumjeti tu razliku između Vrančićeva rječnika i njegova djela Xivvot nikoliko izabraniih divoiicz? Kako objasniti taj "pomak"?

\section{Lodereckerov rječnik}

U tome nam može pomoći Dictionarium septem diversarum linguarum češkoga benediktinca Petra Lodereckera, ${ }^{44}$ objelodanjen godine 1605., koji

ma uzorku pöp, pòpa, kada se rabi u pravome značenju, ali kada označuje crkveni blagdan, da joj je naglasak u množini ovakav: nominativ Dühovi, genitiv Duhóvā (i Dühōvā), dativ, lokativ i instrumental Duhòvima (i Dühovima) te akuzativ Dühove, tj. prema uzor$\mathrm{ku}$ drûg, drûga. Da doista jest posrijedi spomenuti uzorak, vidi se, među ostalim, i po tome što Klaić navodi da kratkosilazni naglasak iz akuzativa množine skače na prednaglasnicu pa bude npr. nä_Duhove (kao što je i zä_drugove). Ne zbiva se dakle novoštokavski pomak siline za jedan slog ulijevo, recimo ovako: ${ }^{*}$ à D Duhove. No upravo takav naglasak u množini neizravno pokazuje da je $\mathrm{u}$ jednini naglasak zapravo Dûh, Dûha. A tako je imao i profesor László, koji je takve imenične osnove običavao nazivati »dugim bezvisicama « (taj se naglasak može potvrditi na više mjesta u profesorovim radovima, ali primjerice u njegovu dosad neobjavljenome Jèz'ikovnìku nalazimo ovako (str. 31): »duhòvnī - nà dūh se odnòsēćī«).

42 Vidi Rječnik hrvatskoga ili srpskoga jezika, sv. I. - XXIII., Jugoslavenska akademija znanosti i umjetnosti, Zagreb, 1880. - 1976., dio II., str. 871. Riječ je o četvrtome svesku toga drugoga dijela (ili o četvrtome sveščiću drugoga sveska), koji je objelodanjen 1886., dakle 15 godina prije Broz-Ivekovićeva rječnika, što znači da je "ispravak" Vukova naglaska mogao biti u nj unesen.

43 Stupac 151. (obrojeni su stupci).

44 Puni naslov vidi u Popisu uporabljenih djela na kraju rada. Navodim redovito 
se općenito smatra drugim izdanjem Vrančićeva rječnika, jedino što su mu pridodana još dva stupca, tj. još dva jezika: češki i poljski. Osim toga sedmojezičnoga rječnika Loderecker donosi i pojedine dvojezičnike: talijansko-latinski, hrvatsko-latinski, ${ }^{45}$ češko-latinski, poljsko-latinski, njemačko-latinski i mađarsko-latinski. Usporede li se hrvatski stupci u Vrančića i u Lodereckera, može se uočiti da je u Lodereckerovu sedmojezičnome rječniku (oznaka L7), a pogotovo u njegovu dvojezičniku (oznaka L2), broj hrvatskih riječi koje su obilježene nekim nadslovkom, ili pak onih pisanih udvojenim suglasnicima, znatno manji negoli u Vrančićevu. Jedino je za udvojene samoglasnike moguće ustvrditi da se dobro "održavaju", tj. da su (većinom) preneseni. To je "opadanje" ili "izostavljanje" nadslovaka s pojedinih riječi pri "prijenosu", kao i "uklon" udvajanja suglasnika, vrijedno podrobno prikazati. No budući da Loderecker nema onih triju dodataka koji se nalaze u Vrančićevu rječniku (U, IC i SA), primjere koji se javljaju u tim dodatcima, potrebno je prethodno oduzeti od ukupnoga broja riječi koje su u Vrančićevu rječniku obilježene nekim nadslovkom ili su pisane udvojenim samoglasnicima ili suglasnicima. Kako to izgleda po pojedinim “kategorijama" (László: »razredcima«), tj. po pojedinim vrstama obilježenosti, pokazuje ova preglednica:

\begin{tabular}{|c|c|c|c|}
\hline & $\begin{array}{c}\text { Vrančić ukupno } \\
\left(\mathrm{V}_{\mathrm{U}}\right)\end{array}$ & $\begin{array}{c}\text { Vrančić u } \\
\text { dodatcima }\left(\mathrm{V}_{\mathrm{D}}\right)\end{array}$ & $\begin{array}{c}\text { Vrančić bez } \\
\text { dodataka }\end{array}$ \\
\hline tupi znak & 223 & 19 & 204 \\
\hline oštri znak & 56 & 1 & 55 \\
\hline zavinuti znak & 4 & 0 & 4 \\
\hline $\begin{array}{c}\text { udvojeni } \\
\text { samoglasnici }\end{array}$ & 486 & 65 & 421 \\
\hline udvojeni suglasnici & 212 & 11 & 201 \\
\hline dva nadslovka & 2 & 0 & 2 \\
\hline Ukupno & $983-12=\mathbf{9 7 1}$ & $\mathbf{9 6}$ & $887-12=875$ \\
\hline
\end{tabular}

Pošto se dakle oduzmu primjeri u dodatcima, u popisu preostaje 887 riječi pojavnica (tj. $875+12$, zbog onih 12 pojavnica "viška" koje se nalaze u popisu), od čega 263 primjera s nadslovkom (204 s tupim znakom, $55 \mathrm{~s}$ oštrim znakom i 4 sa zavinutim znakom), 421 primjer s udvojenim prema pretisku Loderecker 2005.

45 Da se može govoriti o hrvatsko-latinskome dvojezičnome rječniku, vidi se po tome što Loderecker za latinske riječi Dalmata, Dalmatia i Dalmatice navodi Harvat, Harvatfka Zemle i Harvatjky (što je drugačiji zapis za Harvatfkij, a to opet valja odčitati kao Harvat fkii). Tri se navedene latinske riječi ne nalaze u Vrančićevu rječniku. Inače, taj neveliki hrvatsko-latinski rječnik zapravo je prvi tiskani hrvatski dvojezični rječnik gdje je hrvatski polazišni jezik. 
samoglasnikom, 201 primjer s udvojenim suglasnikom te 2 primjera s dvama (istovjetnim) nadslovcima. Prema tome, $u$ dodatcima nema nijedne riječi obilježene zavinutim znakom te također nijedne riječi obilježene dvama nadslovcima. Sada je istom moguće prikazati usporedbu Vrančićeva i Lodereckerova rječnika. ${ }^{46}$ Evo preglednice:

\begin{tabular}{|c|c|c|c|c|}
\hline & $\mathrm{L} 7$ & $\begin{array}{c}\left(\mathrm{V}_{\mathrm{U}}-\mathrm{V}_{\mathrm{D}}\right) \text { - L7 } \\
(\text { ispravljeno })\end{array}$ & $\mathrm{L} 2$ & $\begin{array}{c}\left(\mathrm{V}_{\mathrm{U}}-\mathrm{V}_{\mathrm{D}}\right)-\mathrm{L} 2 \\
\text { (ispravljeno })\end{array}$ \\
\hline tupi znak & 99 & 105 & 45 & 159 \\
\hline oštri znak & 23 & 32 & 14 & 41 \\
\hline zavinuti znak & 0 & 4 & 0 & 4 \\
\hline $\begin{array}{c}\text { udvojeni } \\
\text { samoglasnici }\end{array}$ & 394 & 27 & 224 & 197 \\
\hline $\begin{array}{c}\text { udvojeni } \\
\text { suglasnici }\end{array}$ & 78 & 123 & 60 & 141 \\
\hline $\begin{array}{c}\text { dva } \\
\text { nadslovka }\end{array}$ & 2 & 0 & 0 & 2 \\
\hline Ukupno & $596-\mathbf{4 = 5 9 2}$ & $291-\mathbf{8 = 2 8 3}$ & $343-1=\mathbf{3 4 2}$ & $544-11=\mathbf{5 3 3}$ \\
\hline
\end{tabular}

Dakle, od 204 riječi koje su u Vrančićevu rječniku obilježene tupim znakom, $\mathrm{u}$ Lodereckerovu je sedmojezičnome rječniku tupi znak uklonjen $\mathrm{s}$ njih 105, a u dvojezičnome sa 159 pa je njime u potonjem obilježeno samo 45 riječi. Slično je i s oštrim znakom, koji je u L7 uklonjen s 32 riječi, a u L2 s 41 riječi (od 55, koliko ih je tim znakom obilježeno u Vrančićevu rječniku). To pak znači da je u Lodereckerovu hrvatsko-latinskome dvojezičniku oštrim znakom obilježeno svega 14 riječi. Zavinutoga znaka nema ni u L7 ni u L2, a što se tiče udvajanja suglasnika, ono je uklonjeno sa 123 riječi u L7 te sa 141 u L2 (od 201 riječi, koliko ih je u Vrančićevu rječniku obilježeno udvajanjem suglasnika). To znači da u L2 ima samo 60 riječi s udvojenim suglasnicima. Dva su primjera s dvama nadslovcima prenesena $u$ L7, ali su u L2 oba primjera navedena bez nadslovaka. Jedino što se ipak održava, jest udvajanje samoglasnika, premda i to opada u L2. Tako je od 421 riječi obilježene udvojenim samoglasnicima u Vrančićevu rječniku, u L7 uklonjeno udvajanje u samo 27 riječi (udvajanja su prenesena u 394 primjera), dočim je u L2 udvajanje uklonjeno u 197 riječi, a 224 primjera prenesena su iz Vrančićeva rječnika s udvojenim samoglasnicima. U dvojezičniku bismo, prema tome, imali ovako: 45 riječi s tupim znakom, 14 riječi s oštrim znakom, 60 riječi s udvojenim suglasnicima i 224 riječi s udvojenim

46 Cjelovitu usporedbu svih (nekako) obilježenih riječi u Vrančićevu rječniku s odnosnim primjerima iz Lodereckerova rječnika, i to kako onoga sedmojezičnoga, tako i dvojezičnoga, donosim u Dodatku. 
samoglasnicima (dakle još uvijek više negoli svih ostalih zajedno). Gledajući samo sa stajališta porabe nadslovaka te udvajanja samoglasnika i suglasnika, stječe se dojam kao da L7 i L2 stoje nekako "po sredini" između Vrančićeva rječnika i njegova djela Xivvot nikoliko izabraniih divviicz, tj. kao da L7 i L2 tvore svojevrsne "postaje" na tome putu uklanjanja nadslovaka i udvojenih suglasnika. No koji su razlozi takvu postupku?

\section{Odustanak od nadslovaka}

Pitanje je dakle ovo: zašto je Vrančić odustao, ili postupno odustajao, ponajprije od bilježenja nadslovaka? Prije samoga odgovora valja prethodno iznijeti redoslijed događaja. Premda je Vrančićev rječnik objelodanjen 1595. te se u posveti Alfonsu Carillu navodi nadnevak od 25. kolovoza iste godine (»Venetijs 25. Augulti. 1595. «) ${ }^{47}$ sam je rječnik dakako nastao prije, »ante multos annos «, ${ }^{48}$ kao što $u$ toj posveti kaže sam Vrančić. Izvorno su međutim, kako smatra Josip Vončina, bila zapravo dva rječnika: temeljni (latinsko-talijansko-njemački), koji je nastao oko 1575., u vrijeme Vrančićevih studentskih dana u Italiji te drugi (hrvatsko-mađarski), koji je sastavljen znatno poslije, u Vrančićevim zrelim godinama, a oba su sklopljena u (petojezičnu) cjelinu između 1585. i 1590. godine (Vončina 1979: 9-13). U predgovoru toj cjelini, na što je već upozoreno, Vrančić ne spominje nadslovke, no u samome je petojezičnome rječniku njihova poraba ipak dobro potvrđena. Izdanje na žalost obiluje propustima, ${ }^{49}$ osobito što se tiče nadslovaka (ali ne samo njih). Rječnik je objavljen u Mletcima, talijanski slovoslagar zacijelo nije znao hrvatski, ali očevidno ni njemački pa i tu ima dosta tiskarskih pogrješaka (Vončina 1979:15-16). Posebno je pak pitanje jesu li se u Vrančićevu rukopisu nadslovci uzajamno jasno razlikovali. $^{50}$

Pošto je rječnik bio objelodanjen, Vrančić je jamačno uočio pojedine tiskarske propuste, posebice one u pogledu nadslovaka. Kada je u prosincu

47 Računamo li dakle naslovnicu rječnika kao prvu stranicu, taj bi se nadnevak nalazio na str. 4.

48 To bi bila str. 3, i opet računamo li naslovnicu rječnika kao prvu stranicu.

49 Kako kaže Arturo Cronia »evidenti e banali errori di stampa« (1953:129).

50 Navedeno pitanje razotkriva ujedno koliko je za proučavanje nadslovaka važno imati uvid u rukopis te koliko tiskano izdanje može biti varljivo. U tome se upravo ogleda sva razlika prema istraživanju nadslovaka u Vitezovićevu Lexiconu, koje je u cjelini provedeno na rukopisu. No ni u Vitezovića nije sve uvijek lako odgonetljivo; tako je primjerice oštri znak pisan koliko-toliko jasno, međutim na mnogim mjestima nije svagda lako razabrati je li riječ o tupome znaku ili o zavinutome (kojemu je lijevi krak, recimo, posve skraćen). 
1604. te u siječnju i veljači 1605. boravio u Pragu (Dukat 1925:126), ${ }^{51}$ Vrančić je za Lodereckerov rječnik napisao predgovor s onim neobičnim naslovom »Fauft Vranclich Sibenclanin«. Sam je predgovor pisan na Svijećnicu, 2. veljače, kako se vidi iz nadnevka: »U Pragu na dan ocfifchyenya Blaxenee Divee Mariee. 1605. « To znači da je sročen gotovo pet mjeseci prije preostalih šest predgovora (latinskoga, talijanskoga, češkoga, poljskoga, njemačkoga i mađarskoga), koji su sastavljeni u predvečerje sv. Ivana Krstitelja (latinski: »Pragæ in Vigilia Ioh. Bapt. Anno 1605.«), dakle 23. lipnja (Dukat 1925:123). ${ }^{52} \mathrm{~K}$ tomu, Vrančićev se predgovor sadržajem bitno razlikuje od ostalih, a posve se slaže (tj. znatnim dijelom podudara) s dodatkom pod naslovom De Slovvinis Jeu Sarmatis, ad Chriftophorum Varfovicium Canonicum Cracovien fem, što ga je objavio na kraju djela Xivvot nikoliko izabraniih divviicz (1606./1995:117-119). Napokon, svi ostali predgovori imaju sličan naslov (latinski: Ad Lectorem beneuolum præfatio), koji se također posve razlikuje od već spomenuta naslova Vrančićeva predgovora.

Dakle, kada je Lodereckerov rječnik objavljen, Vrančić više nije bio u Pragu, ali je za svoga boravka u tome gradu očevidno upozorio na propuste u svome rječniku, i to kako samoga Lodereckera, tako i njegova suradnika, koji je, čini se, (uglavnom) radio na hrvatsko-latinskome dvojezičniku (Dukat 1925:130-131). ${ }^{53}$ Može biti da je ostavio i jedan primjerak svoga rječnika s unesenim ispravcima (Katičić 2005:37). ${ }^{54}$ Pri tome je zacijelo naznačio i to da se nadslovci uklone. U izdanju međutim to nije učinjeno u potpunosti, pogotovo u sedmojezičnome rječniku (ali nisu uklonjeni ni svi propusti: dapače, napravljeni su i neki novi) (Samardžija 2005:61-65).

Vrančić je tu svoju zamisao o nebilježenju nadslovaka proveo (u najvećoj mjeri) istom godinu dana poslije $\mathrm{u}$ djelu Xivvot nikoliko izabraniih divviicz, gdje je, $\mathrm{u}$ dodatku pod naslovom De ratione legendi, pače i izrijekom ustvrdio da se ne želi služiti crticama (lineolis), poput Grka, ni piknjama (punctis), poput Hebreja. Pri tome je naveo i razloge zašto se njima ne želi služiti. Tako je u rasponu od kakvih desetak godina, razočaran velikim brojem propusta $\mathrm{u}$ svome petojezičnome rječniku, $\mathrm{u}$ potpunosti odustao od bilježenja nadslovaka pa je godine 1606., pri zapisu hrvatskih riječi u Xivvotu nikoliko izabraniih divviicz, uz mjestimično udvajanje suglasni$\mathrm{ka}$, doista rabio samo udvajanje samoglasnika.

51 Dukat se u tome oslanja na Vrančićev životopis što ga je za treće izdanje Vrančićeva rječnika godine 1834. sastavio Georgius Gyurikovits (vidi 1834:XIV). Usp. i Katičić 2005:37.

52 Usp. i Katičić 2005:31-39.

53 Dukat štoviše kaže da je Vrančić ovlastio Lodereckera da iznova objavi njegov rječnik (1925:126).

54 Vrančić je otišao iz Praga krajem veljače (isto). 


\section{DODATAK}

\section{POPIS PRIMJERA}

\section{Uvodna bilješka}

U ovome dodatku donosim sve riječi pojavnice iz Vrančićeva rječnika koje su obilježene nekim nadslovkom, kao i sve riječi pojavnice s udvojenim samoglasnicima i suglasnicima. Riječi pak koje su obilježene dvama nadslovcima, navodim izdvojeno (takva su samo dva primjera). Pri tome strogo poštujem Vrančićev zapis, uključujući veliko i malo slovo, a prenosim i različite propuste, uglavnom tiskarske pogrješke. Tada u uglatim zagradama navodim "ispravan" lik, tj. lik koji se očekuje. Tako primjerice za Vrančićev zapis Hnopoot (u latinskoj natuknici tussis) upozoravam da je posrijedi vjerojatno riječ Hropoot. U tim slučajevima rabim kraticu tj., dakle ovako: Hnopoot [tj. Hropoot]. Katkada međutim, također u uglatim zagradama, navodim kako bi neki ne posve uobičajeni lik valjalo pročitati (pa dakle i izgovoriti). Recimo, u Vrančićevu se zapisu Vrá (u latinskoj natuknici hora) ne mora odmah prepoznati Urá, niti će lik Vvenul (u natuknici flaccidus) svatko na prvi pogled pročitati (pa ni izgovoriti) Uvenul. U takvim slučajevima rabim znak jednakosti (tj. =), dakle ovako: Vrá [= Urá], Vvenul [= Uvenul], da bih upozorio da je posrijedi samo drugačiji zapis, a ne propust.

U određenim okolinama (obično između dvaju suglasnika, ali katkada i na kraju riječi nakon suglasnika) slovo y stoji umjesto zapisa $i j$, a potonji opet vrijedi koliko i udvojeni samoglasnik $i$, dakle $i i$, pa je i takve riječi sa slovom $y$ valjalo unijeti među primjere s udvojenim samoglasnicima. Tako primjerice lik Ryz (u natuknici caesura) valja shvatiti kao Rijz, a potonji je jednakovrijedan liku Riiz, što je riječ s udvojenim samoglasnikom. U takvim slučajevima pišem ovako: Ryz [tj. Rijz = Riiz]. Od toga odstupam kada se $y$ nalazi između $g$ i kojega drugoga suglasnika, jer tada skup gy valja odčitati kao $j i$ (tzv. prejotacija). To biva u sljedećim primjerima (22 riječi pojavnice): Gydenye (u natuknici esus), Gylis (također u natuknici esus), (Pomnyu) gymati (u natuknici advertere), (Pomnyu) gymati (u natuknici animadvertere), Gyme (u natuknici nomen), Gymenovan (u natuknici nominatus), Gymenovati (u natuknici nominare), Gymenovati (u natuknici nuncupare), Gynako (u natuknici aliàs), Gynako (u natuknici aliter), Gyndi (u natuknici alibi), Gyni (u natuknici alius), (V) gysztinu (u natuknici profecto), Gyßkati (u natuknici indagare), Gyßti (u natuknici comedere), Gyßtinan (u natuknici certus), Gyßtino (u natuknici certé), Gyzbine (u natuknici epu- 
lae), Gyztina (u natuknici veritas), Gyztinno (u natuknici equidem; taj je primjer, zbog udvojenoga suglasnika $n, \mathrm{tj} . n n$, naveden među riječima s udvojenim suglasnicima), Gyztino (u natuknici scilicet) i Obgyden (u natuknici ambesus). To bi dakle redom bilo: jidenje, jiliš, jimati, jimati, jime, jimenovan, jimenovati, jimenovati, jinako, jinako, jindi, jini, jistinu, jiskati, jisti, jistinan, jistino, jizbine, jistina, jistinno, jistino i objiden. Ovamo pripadaju i dva neobična primjera: Gyigra (u natuknici ludicrum) i Gyilis (u natuknici esca). Dakle jigra i jiliš.

U popisu se nalaze 983 riječi pojavnice, od čega 283 primjera s nadslovkom (223 s tupim znakom, 56 s oštrim znakom i 4 sa zavinutim znakom), 486 primjera s udvojenim samoglasnikom, 212 primjera s udvojenim suglasnikom te 2 primjera s dvama (istovjetnim) nadslovcima. Od toga broja (tj. od 983) treba oduzeti 12 pojavnica, budući da se 10 riječi javlja dva puta, a jedna štoviše i tri puta. Evo tih primjera (11 riječi različnica): Bolijeè (u natuknici satius), jedanput zbog tupoga znaka, a drugi put zbog udvojenoga samoglasnika; Dáár (u natuknici munus), jedanput zbog oštroga znaka, drugi put zbog udvojenoga samoglasnika, a treći put zbog dvaju (istovjetnih) nadslovaka; Hittàr (u natuknici ocyor), jedanput zbog tupoga znaka, a drugi put zbog udvojenoga suglasnika; Kàrà (u natuknici controversia), jedanput zbog tupoga znaka, a drugi put zbog dvaju (istovjetnih) nadslovaka; mukeè (u natuknici simila), jedanput zbog tupoga znaka, a drugi put zbog udvojenoga samoglasnika; Oppekà (u natuknici later), jedanput zbog tupoga znaka, a drugi put zbog udvojenoga suglasnika; Oppovijßt (u natuknici omen), jedanput zbog udvojenoga samoglasnika, a drugi put zbog udvojenoga suglasnika; Peddeßeet (u natuknici quinquaginta), jedanput zbog udvojenoga samoglasnika, a drugi put zbog udvojenoga suglasnika; Roffzà (u natuknici ros), jedanput zbog tupoga znaka, a drugi put zbog udvojenoga suglasnika; Villè (u natuknici furca), jedanput zbog tupoga znaka, a drugi put zbog udvojenoga suglasnika; Zvvir (u natuknici animal, animans), jedanput zbog tupoga znaka, a drugi put zbog udvojenoga suglasnika. To znači da se u Vrančićevu rječniku nalazi ukupno 971 riječ pojavnica koja je na neki način obilježena: bilo nadslovkom, bilo udvajanjem samoglasnika ili suglasnika.

U oblim zagradama donosim potom latinsku natuknicu. Za razliku od hrvatskih primjera, gdje se strogo poštuje Vrančićev zapis, latinske riječi navodim onako kako je danas uobičajeno. To znači da su sve latinske riječi pisane malim početnim slovom, da se dvoglasi ae i oe pišu dvoslovima, a ne spojenicama $x$ i $\propto$, da se ne provodi razlika između $\int$ i $s$ (upravo ( i s), dvaju pismènīh likova istoga grafema, ili istoga pìsmena, kojih je razdioba ionako pretkažljiva (kao u grčkome $\sigma$ i $\varsigma$ ) te da se provodi ra- 
zlika između $v$ i $u$ (zapravo $V$ i $u$ ) u zavisnosti od okoline, tj. od izgovora, premda Vrančić redovito ima $V$ kada je riječ o velikome slovu (npr. Vallis, $V n d a)$, a $u$ kada je posrijedi malo slovo (npr. Acumen, Auena), što znači da ih rabi nezavisno od okoline, tj. od izgovora. Navodim međutim nadslovke, koje Vrančić, premda razmjerno rijetko, bilježi gdjekada i na latinskim riječima. No može se reći da se nadslovci na latinskim riječima u Vrančićevu rječniku, za razliku od Vitezovićeva Lexicona, redovito rabe na neprozodijskoj razini.

Ako je hrvatska riječ koja se navodi u popisu, dio kakve sveze ili izričaja, donosim ju izdvojeno, a uz latinsku otpovjednicu bilježim cijelo značenje kako ga ima Vrančić, tj. cijelu svezu ili izričaj, i to unutar jednostrukih navodnika, a sve u oblim zagradama, primjerice: lijßt [= lii $\beta t]$ (commeatus 'Verni lijßt'). Pri tome i latinsku riječ i značenje u jednostrukim navodnicima pišem običnim (ili uspravnim) slovima (tzv. kurentom).

Među navedenim hrvatskim riječima ima i onih koje se ne nalaze u samome Vrančićevu petojezičnome rječniku, nego u nekome od njegovih triju dodataka. U tome slučaju ne donosim latinsku natuknicu, nego u uglatim zagradama upozoravam o kojem je dodatku riječ i to sljedećim pokratama: Vocabula Dalmatica, quae Ungari sibi usurparunt [U], Institutio Christiana [IC], Symbolum apostolorum [SA].

Sve su riječi iz Vrančićeva rječnika koje navodim ovdje u popisu, uspoređene s odnosnim primjerima $\mathrm{u}$ Lodereckerovu sedmojezičnome rječni$\mathrm{ku}$ (Dictionarium septem diversarum linguarum). Pri tome u uglatim zagradama donosim Lodereckerov lik (s oznakom L7) ako se u njegovu rječniku zapis određene riječi razlikuje od Vrančićeva zapisa. To znači prije svega onda kada je uklonjen nadslovak te udvajanje samoglasnika ili suglasnika, ali mjestimice i onda kada je posrijedi kakva druga razlika, tj. izmjena. Evo kako to može izgledati: Branà (patrocinium) [L7: Brana].

Sve riječi pojavnice iz Lodereckerova dvojezičnoga hrvatsko-latinskoga rječnika (oznaka L2) koje su obilježene nekim nadslovkom, kao i sve riječi pojavnice s udvojenim samoglasnicima i suglasnicima, budući da ih nema previše, pogotovo onih s nadslovcima, navodim izdvojeno na kraju. Latinski prijevod pri tome bilježim samo u onim slučajevima kada je potrebno upozoriti na značenje hrvatske riječi. Uz četiri primjera iz Vrančićeva rječnika sa zavinutim znakom (Karâ, Lûgh, Szvitâ i Szvitâk) te uz dva primjera iz njegova rječnika s dvama (istovjetnim) nadslovcima (Dáár i Kàrà), odnosne primjere iz Lodereckerova hrvatsko-latinskoga rječnika iznimno navodim i u glavnome popisu (u onome iz Vrančićeva rječnika). To primjerice izgleda ovako: Karâ (iurgium) [L7, L2: Kara]. 
U popisu se pak iz spomenutoga Lodereckerova dvojezičnika nalaze 343 riječi pojavnice, od čega 59 primjera s nadslovkom (45 s tupim znakom, $14 \mathrm{~s}$ oštrim znakom, dočim sa zavinutim znakom nema primjera), 224 primjera s udvojenim samoglasnikom, 60 primjera s udvojenim suglasnikom, a s dvama nadslovcima također nema primjera. Od toga broja (tj. od 343) treba oduzeti jednu pojavnicu, budući da se riječ Oppovijßst javlja dva puta, jedanput zbog udvojenoga samoglasnika, a drugi put zbog udvojenoga suglasnika. To opet znači da se u Lodereckerovu hrvatsko-latinskome rječniku nalaze ukupno 342 riječi pojavnice koje su na neki način obilježene: bilo nadslovkom, bilo udvajanjem samoglasnika ili suglasnika. Zapravo, posrijedi su sve same riječi različnice (što se u dvojezičnome rječniku, gdje je hrvatski polazišni jezik, i očekuje), osim ovoga izdvojenoga primjera: Szinnicza (tabernaculum, umbraculum) i Szinnicza (scena). Primjere iz Lodereckerova dvojezičnika, kako one hrvatske, tako i latinske, navodim običnim slovima.

Napokon, u Vrančićevu se rječniku kao prijevod latinske imenice os, ossis navodi riječ, a bolje bi bilo reći - lik Kocißt, što će zacijelo biti tiskarska pogrješka umjesto ispravnoga Kooßt (vjerojatno je talijanski tiskar iz rukopisa drugi o krivo pročitao kao ci). U L7 zapis je tobože ispravljen ovako: Koclst, a u L2 ovako: Koclft. No, koliko god da je lik Kooßt vrlo vjerojatan, tu riječ, budući da u takvu zapisu nije potvrđena u rječniku, ipak nisam uvrstio među riječi s udvojenim samoglasnicima (Vrančić za ebur ima prijevod Lefanya kozt, a za pridjev osseus navodi Od-koßti; za ebur L7 ima kao i Vrančić: Lefanya kozt, a L2: Lefania kolzt, dočim za osseus L7 navodi: Odkolsti, a L2: Od Kollti). 
Nadslovci (283 riječi pojavnice)

TUPI ZNAK (223 riječi pojavnice)



Dinya [U]

Ditè (puer)

Ditinztvò (pueritia) [L7: Ditinztvo]

Dnò (fundum)

Dò (tenus)

Dò (usque)

Dolì (deorsum)

dragà (vallis) [L7: Dragá]

Drivò (lignum)

Evò (ecce)

Garbà (gibbus) [L7: Garba]

Gigrà (ludus) [L7: Gigra]

glaßà (infamis 'Zla glaßà')

Gnyidà (lens) [L7: Gnyida]

Gorà (mons) [L7: Gora]

Gutà (podagra)

Guzlè (lyra) [L7: Guzle]

Gyamà (caverna) [L7: Gyama]

Hittàr (ocyor) [L7: Hittar]

Hotè (ultrò) 
Hròm (loripes) [L7: Hrom]

Ifztòk (oriens)

Iz-nutrà (intrinsecus)

izvedè [IC]

Kà (versus)

Kadì (ubi) [L7: Kadi]

Kakò (quemadmodum) [L7:

Kako]

Kakò [SA]

Karà (lis)

Karà (rixa) [L7: Kara]

Kàrà (controversia)

Knyigè (liber)

Kokòs (gallina) [L7: Kokos]

Kolà (carpentum)

Kopilò (nothus)

Korà (cortex)

Korà (crusta)

Koßà (falx)

Kotàl (lebes)

Koxà (pellis)

Kriv (limus) [L7: Kriv]

Liczè (gena) [L7: Licze]

Linòßt (ignavia) [L7: Linolst]

lozè (palmes 'Prut-od lozè')

Maglà (nebula)

Malò (paulum) [L7: Malo]

Manyè (minus)

Meàs (limes) [L7: Meas]

Mecsà (pulpa) [L7: Mecsa]

Meù (intra)

Mirà [U]

Mißstò (civitas)
Mißtò (locus) [L7: Mifsto]

Modàr (lividus) [L7: Modar]

Mogù (possum) [L7: Mogu]

Morè (mare)

Mucsè (occultè) [L7: Mucse]

Mudrò (prudenter)

Mukà (vexatio)

mukeè (simila 'Czvit-od-mukeè')

[L7: cfvit od mukeè]

Nay paruò [tj. Nay parvò] (imprimis) [L7: Nayparvo]

Nè (ne)

nè (quidni 'Zalto nè') [L7:

Zaltone]

nè (quin? 'Kako nè?') [L7: Kakone]

Negò (quàm) [L7: Nego]

Nelagod Jztvò (languor) [L7:

Nelagod[ztvo]

Nikolikò (aliquantum) [L7: Nikoliko]

Nikolikò (aliquot) [L7: Nikoliko]

Nò (eia)

Nogà (tibia pedis) [L7: Noga]

$\mathrm{Nù} \mathrm{[U]}$

Obvalà (septa) [L7: Obvala]

Odonde-yßtò (indidem) [L7:

Odondey[stò]

Okò (oculus) [L7: Oko]

Omelà (viscus)

Oppekà (later)

Oràl (aquila)

Orudyè (organum) [L7: Orudye]

Oftrò (acies) [L7: Oftro] 


\begin{tabular}{|c|c|}
\hline Oftrò (acumen) [L7: Oftro] & Rotà (iuramentum) [L7: Rota] \\
\hline Oftrogà (calcar) & Rugò (ludibrium) \\
\hline oßlà [IC] & Schyenè (catulus) [L7: Schyene] \\
\hline Ovò (hoc) [L7: Ovo] & firinà (laxitas) [L7: Sirina] \\
\hline Ovràth (orata) & Skodà (intertrimen[t]um) \\
\hline Ovudà (hac) & Sponè (pedica) \\
\hline Pacsè (quin) [L7: Pacse] & ftò (quid) [L7: Stó] \\
\hline Pakàl (infernus) & Svudà (passim) [L7: Svuda] \\
\hline $\begin{array}{l}\text { Parßurà (frixorium) [L7: } \\
\text { Parfsura] }\end{array}$ & $\begin{array}{l}\text { Szamò (tantum) [L7: Szamo] } \\
\text { Szelò (pagus) }\end{array}$ \\
\hline Paßà (pascuum) & Szenò (foenum) [L7: Szeno] \\
\hline Petà (calcaneus) & Szilà (violentia) \\
\hline Pifsiczè (pedester) & Szilà (vis) \\
\hline Plemè (generatio) & Szitò [U] \\
\hline Plemè (prosapia) & Szlobòd (licentia) [L7: Szlobod] \\
\hline Plemenztvò (ingenuitas) [L7: Ple- & Szokòl (falco) \\
\hline $\begin{array}{l}\text { menztvo] } \\
\text { Pliszàn (mucor) [L7: Plifzan] }\end{array}$ & $\begin{array}{l}\text { Szramotà (ignominia) [L7: Szra- } \\
\text { mota] }\end{array}$ \\
\hline Pò (per) [L7: Po] & Szridà (medietas) \\
\hline Pò (secundum) [L7: Po] & Sztadò (grex) \\
\hline Podpòr (columen) [L7: Podpor] & Sztàn (domicilium) [L7: nedosta- \\
\hline Poglèd (aspectus) & je] \\
\hline Pohvè (postilena) & Sztò (centum) [L7: Szto] \\
\hline Pòl (semis) & Szuknò (pannus) [L7: Szukno] \\
\hline Prigodà (occasio) [L7: Prigoda] & Szvakoyakò (omnifariam) \\
\hline Pulè (hinnulus) & Szvità-zahod (vertigo) [L7: Szvi- \\
\hline Puztò [U] & ta, Zahod] \\
\hline Radà (libenter) [L7: Rada] & $\begin{array}{l}\text { Blamè (stramineus 'Od-ßlamè') } \\
\text { [L7: Od Szlame] }\end{array}$ \\
\hline Radà (lubens) & Btranè (quoquoversum 'Na-ßve- \\
\hline Ranà (vulnus) & -Btranè') [L7: NaIsvelstrane] \\
\hline Rebàcz (passer) & Takò (sic) \\
\hline Rezti (gliscere) [L7: Rezti] & Tarnyè (vepres) \\
\hline os) [L7: Rol & Tarpì [SA] \\
\hline
\end{tabular}


Telè (vitulus)

Texàk (colonus)

Timè (sinciput) [L7: Time]

Tifztò (massa) [L7: Tifzto]

Tlò (pavimentum) [L7: Tlo]

Tlò (solum)

To-boxè (nempè)

ù [IC]

ù $[\mathrm{SA}]$

ù $[\mathrm{SA}]$

ù $[\mathrm{SA}]$

Vàn (extra) [L7: Van]

Vàrßt (conditio)

Vboftvò [= Uboftvò] (inopia) [L7:

Vboltvo]

Vdò [= Udò] (membrum) [L7:

Vdo]

Velè (multum)

velè (nimis)

Vidrà (lutra) [L7: Vidra]

Vidrò (hydria)

Villè (furca) [L7: Ville]

Vinò (vinum) [L7: Vino]

volà [IC]

Voßàk (cera) [L7: Volsak]

Vratàr (ianitor) [L7: Vratar]

OŠTRI ZNAK (56 riječi različnica)

akó (sin ‘Dà-akó-ne') [L7: Dà akone]

Báth (clava)

Blatán (limosus) [L7: Blatan]

Brafnó (esca) [L7: Bralno]

Csrivá (intestina)
Vrimè (tempus) [L7: Vrimé]

Vtokà [= Utokà] (perfugium) [L7:

Vtoka]

Vunà (lana)

vunè (laneus ‘Od-vunè') [L7: Od vune]

Vztà [= Uztà] (orificium) [L7:

Vzta]

Xalò (glarea) [L7: Xalo]

Yakò (fortiter) [L7: Yako]

Yamàcz (obses)

Yajzlò [U]

Yavòr (laurus) [L7: Yavor]

Yedvà (vix)

Zà (ob)

Zà (pro)

Zakòn (lex)

Zarnò (granum) [L7: Zarno]

Za-ßidà (insidiae) [L7: Zalsidà]

Za-tò (igitur) [L7: Zatò]

Zatò (propterea) [L7: Zato]

Zkupò (avarè) [L7: Zkupo]

Zlò (perperam) [L7: Zló]

Zlobà (malitia) [L7: Zloba]

Zvoì (animal, animans) [L7:

Zvìr]

Dá (ast)

Dáár (munus)

Dásy (imber) [L7: Dafy]

Dó (adusque)

Dobrotá (bonitas)

Grudá (gleba) [L7: Gruda] 
Hitró (raptim) [L7: Hitro]

i (ac) [L7: I]

Ká $(\mathrm{ad})$

Kód (iuxta)

Kós (canistrum)

Kotál (cacabus) [L7: Kotal]

Kúp (acervus) [L7: Kup]

Laná (linteus ‘Od Laná') [L7: Od Lana]

Lóv (venatio)

Mís (mus) [L7: Mis]

Mnogo frúk [tj. Mnogoftrúk] (multiplex) [L7: Mnogoftúk, tj.

Mnogoftrúk]

Moré (aequor) [L7: More]

Móy (meus) [L7: Moy]

Mráz (gelu)

Múka (labor)

Ná (en)

né (ferè ‘Malo-da né') [L7: Malodane]

Nú (age)

Obál (orbiculatus)

Pará [U]

Páß (canis)

Peró (penna) [L7: Pero]

Plá-voyßka (classis) [L7:

Plavvoy[ska]

ZAVINUTI ZNAK (4 riječi različnice)

Karâ (iurgium) [L7, L2: Kara]

Lûgh (cinis) [L7, L2: Luugh]

Szvitâ (stola) [L7: Szvitá, L2: Szvi-

tà]
Plechyé (armus) [L7: Plechye]

Polí (iuxta) [L7: Poli]

Polyé (campus) [L7: Polye]

Po-maló (paulatim) [L7: Pomalo]

Potóp (diluvium)

Prág (limen)

Púh (glis)

Ranné [tj. Ramé] (humerus) [L7:

Ramié]

Razlucsít (diversus) [L7:

Razluclit]

Razpáß (discinctus 'Raz páß')

Skodá (damnum) [L7: Skoda]

Strosák (impensa) [L7: Strolak]

Szaló (abdomen)

Szláb (laxus) [L7: Szlab]

Tvardo-vrát (obstinatus) [L7:

Tvardo vrát]

Verá (fides) [L7: Vera]

Vrá [= Urá] (hora) [L7: Vra]

Vsgáti [= Usgáti] (incendere) [L7:

VIgati]

Yató (agmen) [L7: Yatò]

Zglób (iunctura) [L7: Zglob]

Zorá (aurora) [L7: Zora]

Zponé (compedes) [L7: Zpone]
Szvitâk (cicindela) [L7, L2: Szvitak] 


\section{Udvojeni samoglasnici (486 riječi pojavnica)}

\begin{tabular}{|c|c|}
\hline Baan (praeses) & Cseeßt (creber) [L7: Cleefst] \\
\hline Baaz (sambucus) & Cseeßt (frequens) \\
\hline Baaz [U] & Cselyuußt (rictus) \\
\hline Bahaat (strepitus) & Csetiri-ß3too (quadringenti) [L7: \\
\hline Bdechii (vigil) [L7: Bdechij] & \\
\hline Bdechij [= Bdechii] (vigilans) & $\begin{array}{c}\text { Csetuartoocs [= Csetvartoocs }] \\
\text { (quartum) }\end{array}$ \\
\hline Biil (albus) & \\
\hline Bijß [= Bii $\beta]$ (rabies) [L7: Byils] & CSETVARTAA [IC] \\
\hline Blaag (liberalis) & Csriip (testa) \\
\hline Blaag (munificus) & Csryp [tj. Csrijp = Csriip] [U] \\
\hline Bliid (luridus) [L7: Blijd] & Cziiv (tubus) [L7: Czijv] \\
\hline Bliid (pallidus) [L7: Blijd] & Czilij [tj. Czily, ne Czilii] (meta) \\
\hline Bluud (menda) & Czilij [tj. Czily, ne Czilii] (scopus) \\
\hline Bolijeè [tj. bolyeè] (satius) [L7: & Czvijtk [= Czviitk $]$ (flos) \\
\hline Bolyèe] & $C z y l[$ tj. $C z i j l=C z i i l]$ (integer) \\
\hline Boog [IC] & Daan (dies) \\
\hline Boogh (numen) & daan [IC] \\
\hline Book (latus) & daan [SA] \\
\hline Book (lumbus) & Daar (strena) \\
\hline Bool (dolor) & Dáár (munus) \\
\hline Boor (larix) & Darhaat (tremor) \\
\hline $\begin{array}{l}\text { Braad [tj. Graad] (arx) [L7: } \\
\quad \text { Graad] }\end{array}$ & $\begin{array}{l}\text { Davnij [= Davnii] (priscus) [L7: } \\
\text { Davnyi] }\end{array}$ \\
\hline Braak (matrimonium) & Deefzna (gingiva) \\
\hline Briißßt (fagus) [L7: Brij $\{s t]$ & deeßnu [SA; na deеßnu] \\
\hline Brood (vadum) & DESZETAA [IC] \\
\hline Вruи $\beta(\cos )$ & DEVETAA [IC] \\
\hline$b y[\mathrm{tj} . b i j=b i i][\mathrm{SA}]$ & Devet- $\beta$ too (noningenti) \\
\hline By $[\mathrm{tj} . b i j=b i i][\mathrm{SA}]$ & Diil (pars) [L7: Dijl] \\
\hline$b y[\mathrm{tj} . b i j=b i i][\mathrm{SA}]$ & Dijl [= Diil] (portio) \\
\hline Chijuuk [tj. Chyuuk] [U] & diviczee $[\mathrm{SA}]$ \\
\hline Csaaßt (officium) & Divßstvoo (virginitas) \\
\hline
\end{tabular}


Divyaa maßlina (oleaster) [L7: Divya malslina]

Divyij-Oßal [= Divyii-Oßal] (onager) [L7: Divyi Olsal]

Dlaan (vola)

Dobijt [= Dobiit $]$ (victus)

Druug (comes)

druug (socius)

DRUGAA [IC]

Duub (quercus)

Duuga (iris)

Duugh (debitum)

Duuh (spiritus)

Egipacskee [IC]

Gaard (deformis)

Giid (virus) [L7: Gijd]

Giißkati (quaerere) [L7: Gijfskati]

Gijzti [= Giizti] (edere)

gißty [tj. gißtij = gißtii] (idem 'Taa gißty') [L7: Taagilsti]

Glaad (fames)

Glaafz (rumor)

Glaajz (sonus)

Glaajz (vox)

Glaaß (fama)

glaaß (vocula 'Mal-glaaß') [L7:

Malglaais]

Gluuh (surdus)

Glyedaa (spectator 'Koyi Glyedaa') [L7: Koyi Glyeda]

Glyzte [= Gliizte] (lumbrici)

Gniil (fracidus) [L7: Gnijl]

Gniil (tabidus) [L7: Gnijl]

Gnilaad (putredo)
Gnyilaad (tabes)

Gool (nudus)

Goozt (hospes)

Gorii (peior) [L7: Gorij]

Graad (oppidum)

Graad (urbs)

Griih (erratum) [L7: Grijh]

Gruub (deformis)

Gußaar (grassator)

Guußt (densus)

Guuzt (spissus)

Gyakoofzt (robur)

Habaath (ebulum)

Hchij [= Hchii] (filia)

Hiit (iactus) [L7: Hijt]

Hood (gressus)

Hnopoot [tj. Hropoot] (tussis)

Hraazt [U]

Hropoot [U]

Huud (miser)

Huud (vilis)

Huud [U]

Izboor (optio)

Iztook (origo)

Kasznooszt (tarditas)

Kiip (persona) [L7: Kijp]

Kijp [= Kiip] [U]

Klaasz (spica) [L7: Klasz]

Klaasz [U]

Klyn [tj. Klijn = Kliin] (cuneus)

Klyuun (rostrum)

Kneez (dominus)

Koosz (merula) 
Kopaacs (vespillo)

Kriix (crux) [L7: Krijx]

Kruug (scopulus)

Kuuchni (genuini dentes)

Kuusz [U]

Кииß (frustum)

Кииß (offa)

Кииß-zemlye (tractus) [L7:

Kuuls, Zemlye]

Kvaar (dispendium)

Kvaar [U]

Kvaaß (fermentum)

Laan (linum)

Laaxacz (mendax)

Leed (glacies)

Liik (medecina) [L7: Lijk]

Liin (deses) [L7: Lijn]

Liin (ignavus) [L7: Lijn]

Liin (piger) [L7: Lijn]

Liin (reses) [L7: Lijn]

Liin (segnis)

Liip (bellus) [L7: Lijp]

Liip (formosus) [L7: Lijp]

Liip (gluten) [L7: Lijp]

Liip (speciosus) [L7: Lijp]

Liip (venustus) [L7: Lijp]

Liißst (epistola)

Lijn [= Liin] (iners)

Lijp [= Liip] (pulcher)

Lijp [= Liip] [U]

lijß $[=$ liij $\beta t$ (commeatus 'Verni lijßt')

Lijzt [= liizt] (sura) [L7: Lyzt]
Linoozt (torpor)

Liuaa [tj. Livaa] (laeva) [L7:

Livaa]

lozee (pampinus 'Lylt-od-lozee')

Ludoofzth (socordia)

Luucs (teda)

Luud (delirus)

Luud (fatuus)

Luud (stolidus)

Luud (stultus)

Luug (nemus)

Luug [U]

Luugh (lixivium)

Luugh (saltus)

Luugh (sylva)

Lü̈gh [tj. Luugh] (lucus)

Luuk (arcus)

Lyn [tj. Lijn = Liin] (tardus)

Lyft [tj. Lijft = Liift] (pampinus

'Lyft-od-lozee')

Lyuuly (lolium) [L7: Livuly]

Lyuut (mordax)

Lyuut (saevus) [L7: Lyuud, tj.

Lyuut]

maah (lanugo 'Zali-maah') [L7:

Zali maah]

maah (pluma)

Maah [U]

Maal (modicus)

Maal (parvus)

Maal (paucus)

mateer [IC]

Meed (mel)

Meed [U] 
Meehkotiti (mollire)

Meu-too (interim) [L7: Meutoo]

Miih (uter) [L7: Mijh]

miil (carus) [L7: Mijl]

Mij [= Mii] (nos) [L7: My]

$\operatorname{Mij}[=\mathrm{Mii}]$ [U]

mij $[=$ mii] $[\mathrm{SA}]$

Mlaad (iuvenis)

Mlaad (tener)

Mlaak (tepidus)

Mladooßt (iuventus)

Mnoog (numerosus)

Mnoftvoo (multitudo) [L7:

Mnoftvo]

Mooch (efficatia)

Mooch (potentia)

Mooßt (pons)

Mraa[k] (obscuritas)

mukeè (simila 'Czvit-od-mukeè')

[L7: clvit od mukeè]

Muuka (farina)

Muux (maritus)

Muux (vir)

Myr [tj. Mijr = Miir] (pax)

naam [SA]

naaß [SA]

naaß [SA]

Naduut (turgidus)

Nagnuut (pronus)

Nagnuut (propensus) [L7: Nagnut]

Nazaad (retrorsum)

Ne szpoor (prodigus) [L7:

Neszpoor] nebeßaа [SA; na nebeßaа]

Nemooch (imbecillitas)

Nijm [= Niim] [U]

Nooch (nox)

Nooß (nasus)

Noox (culter)

Obaal (rotundus)

Obadvaa (uterque)

Obiknuut (usitatus)

Oblaak (nubes)

Obruucs [U]

Oon (ille)

Oon (ipse)

Opeet (vicissim)

Oppovijßt [= Oppoviißßt] (omen)

[L7: Oppovy[st]

OSZMAA [IC; piše: NSZMAA]

Oßam-de[ß]eet (octoginta) [L7:

Olsamdefseet]

Ovcsaar (opilio)

Paah (flatus)

Paaka (deinde)

Paaß (baltheus)

Paaß (cingulum)

pakaal [SA]

Pameet (mens) [L7: Pameeth]

Pameeth (ingenium)

Pameeth (memoria)

Parvoo (primò)

Parvoo (prius)

Peddeßeet (quinquaginta) [L7:

Petde[set]

Peech (caminus)

Peech (fornax) 


$\begin{array}{ll}\text { Peech (furnus) } & \text { Praaznoßt (intervallum) } \\ \text { Peeßt (pugnus) } & \text { Prateex (supellex) } \\ \text { Peet (quinque) } & \text { Prooßt (liber) } \\ \text { PETAA [IC] } & \text { Prooßt (solutus) } \\ \text { Petij [= Petii] (quintus) [L7: Pety] } & \text { propeet [SA] } \\ \text { Pet-ßtoo (quingenti) [L7: Pet[sto] } & \text { Prutyee (virgulta) [L7: Prutye] } \\ \text { Piir (nuptiae) [L7: Pijr] } & \text { Pruuth (virga) } \\ \text { Piifznik (notariu[s]) [L7: Pij[znik] } & \text { Pßoo/zt (vituperium) } \\ \text { Piyaat [tj. Priyaat] (gratiosus) } & \text { Pßooßt (opprobrium) } \\ \text { Plaafch (lacerna) } & \text { Puuk (plebs) } \\ \text { Plaaßaa (iugerum) } & \text { Puuk (populus) } \\ \text { Plijn [= Pliin] (rapina) [L7: Plyn] } & \text { Puuk (vulgus) } \\ \text { Plijs [= Pliis] (calvitium) } & \text { Puut (via) } \\ \text { Plijs [= Pliis] [U] } & \text { Puuth (iter) } \\ \text { Plifzaan (situs) } & \text { Puutnik (viator) } \\ \text { Plood (foetus) } & \text { raacsiti (dedignari 'Ne-raacsiti') } \\ \text { Plood (fructus) } & \text { [L7: Neracsiti] } \\ \text { Plood (germen) } & \text { Raath (cuspis) } \\ \text { Plood [SA] } & \text { Raax (siligo) } \\ \text { Ploot (sepes) } & \text { Raax [U] } \\ \text { Poklyiszaar (nuncius) } & \text { Razboor (ratio) } \\ \text { Pomaaszt (unguentum) } & \text { Razboor (ratiocinatio) } \\ \text { Pool (dimidius) } & \text { Reed (tenor) } \\ \text { Pooszth (ieiunium) } & \text { Reed [U] } \\ \text { Poot (sudor) } & \text { Reep (penis) } \\ \text { Poßluu[h] (obsequium) } & \text { Reezti (crescere) } \\ \text { poßvetiis [IC] } & \text { Riics (dictio) [L7: Rijcs] } \\ \text { Povraaz (funis) [L7: Povraz] } & \text { Riics (verbum) [L7: Rijcs] } \\ \text { Povraaz (restis) } & \text { Riics (vocabulum) [L7: Rijcs] } \\ \text { Praach (fullo) } & \text { Rijz [= Riiz] (fissura) (rima) [L7: Ryz] } \\ \text { Praah (pulvis) } & \text { Rijz [= Riiz] (incisura) [L7: Rijc, } \\ \text { Praaz (caper) } & \text { tj. Rijz] } \\ \text { Praaz (hircus) } & \end{array}$




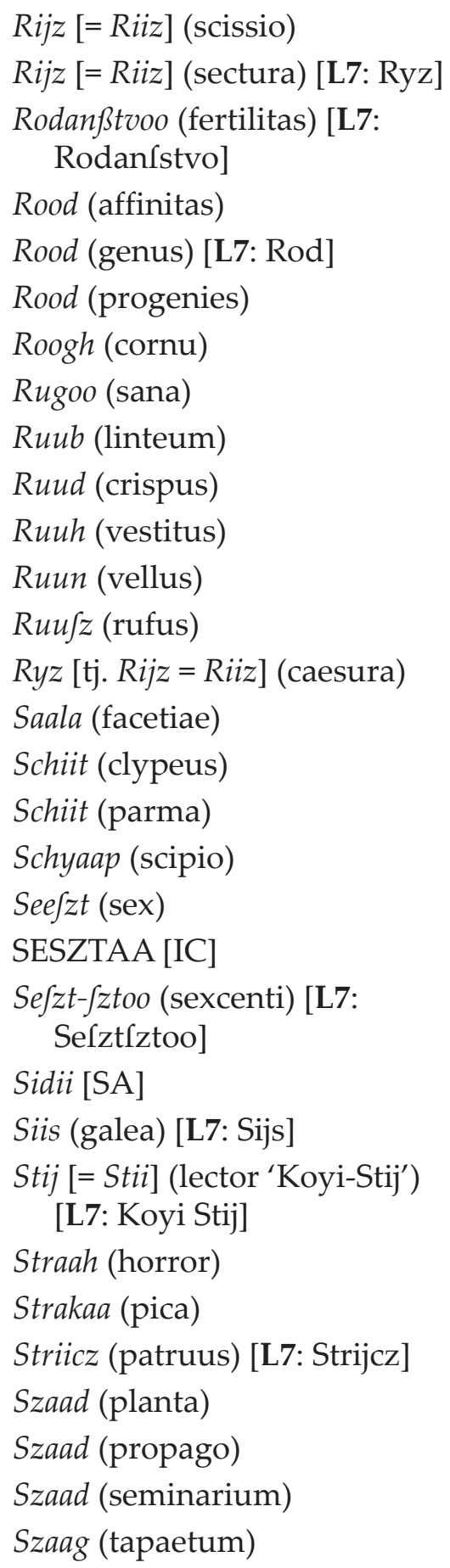

Szaam (solus)

Szaan (insomnium)

Szatreeßti (vibrare) [L7:

Szatrelsti]

Szedam-Sztoo (septingenti) [L7:

Szedam [ztoo]

SZED[M]AA [IC]

Sziid (canus) [L7: Szijd]

Sziik (caesura)

Sziin (filius) [L7: Szijn]

Sziir (caseus) [L7: Szijr]

Szlaaßth (dulcedo)

Szlaaßth (iucunditas)

Szlaazt (sapor)

Szlijp [= Szliip] (orbus)

Szmook (opsonium)

Szmraad (putor)

Szmraad (sordes)

Szmrycs [tj. Szmrijcs = Szmriics] (iuniperus)

Szook (succus)

Szool [U]

Szpoor (frugalis)

Szpravee (seriò)

Szpuux (limax)

Szraam (verecundia)

Szrijs [= Szriis] (muscus)

Sztaan (habitatio)

Sztaan (stabulum)

Sztaar (senex) [L7: Sztar]

Sztaar (veter)

Sztaar (veteranus)

Sztaar (vetus)

Sztaar (vetustus) 





Veezanye (nexus)

Veßeel (laetus) [L7: Velsel]

Vgrijz [= Ugriiz] (morsus)

Vidroo (urna) [L7: Vidro]

Vidroo [U]

Vihaar (nimbus)

Vii (vos) [L7: Vy]

Viid (visus) [L7: Vijd]

Viin [tj. Viir] (gurges) [L7: Vijn]

Vijk [= Viik] (seculum) [L7: Vyk]

Vikuuicsni [tj. Vikuvicsni] (sempiternus) [L7: Vikuvic(ni]

Vitaar (ventus)

Vlaaß (pilus) [nalazi se u njemačkome stupcu, uz Haar] [L7: nedostaje]

vodee (crepido 'Kray-vodee')

Vood (ducatus)

Vooz (currus)

Vooz (vehiculum)

Voynicskii (bellicus) [L7: Voynicski]

Vraath (cervix)

Vtoo [= Utoo] (interea)

Vulaaß [tj. Vvlaaß] (villus) [L7:

Vlaals]

Vuuk (lupus)

Vzaal [= Uzaal] (ligamen)

Vz-goora [= Uz-goora] (sursum) [L7: Vzgora]

Xiuuchi [tj. Xivuchi] (vividus)

Xuucs (fel)

Xuuth (flavus)

Xuuth (fulvus)
Xuuth (luteus)

Yaa [IC]

Yaak (fortis)

Yaak (lacertosus)

Yaak (robustus)

Yavoor [U]

Zaacs (quare)

Zaacs (quia)

Zaal (malus)

zablenuut (stupidus)

zacseet [SA]

ZAPOVIDII [IC]

Zapovijd [= Zapoviid] (mandatum)

Za-ßaad (obsidio) [L7: Zalsaad]

Za-ßuuti (obruere)

Za-too (ideo) [L7: Zatoo]

Zatvoor [U]

Zeecz (lepus)

Zemlyee [IC]

Zemlyee [SA]

Zijd [= Ziid] (murus)

Zlocfeschyaak (nebulo) [L7:

Zlocleschyak]

Zoob (avena)

Zoob [U]

Zpuus (concha)

Zuub (dens)

Zuub (uncus)

Zuuk [tj. Zvuk] (tinnitus) [L7:

Zvuuk]

Zuug [tj. Zvuk] [U]

Zvaan (invitatus) 


\section{Udvojeni suglasnici (212 riječi pojavnica)}

\begin{tabular}{|c|c|}
\hline $\begin{array}{l}\text { Alli (atamen) } \\
\text { Alli (atqui) }\end{array}$ & $\begin{array}{l}\text { Dobrovvnoßth (benignitas) [L7: } \\
\text { Dobrovnofsth] }\end{array}$ \\
\hline Alli (aut) & $\begin{array}{l}\text { Dobroztive (benignus) [L7: Do- } \\
\text { broztiv] }\end{array}$ \\
\hline $\begin{array}{l}\text { Alli (autem) } \\
\text { Alli (vè) }\end{array}$ & $\begin{array}{l}\text { Dobroztive (comis) [L7: Do- } \\
\text { broztiv] }\end{array}$ \\
\hline $\begin{array}{l}\text { Alli (vel) } \\
\text { Barzitifse (accelerare) [L7: }\end{array}$ & $\begin{array}{l}\text { Doßadlyvo [tj. Doßadlyivo] (im- } \\
\text { portunus) [L7: Dolsadlyiv] }\end{array}$ \\
\hline & Doyitt (lactare) [L7: Doyiti] \\
\hline $\begin{array}{l}\text { Bezzakonye (iniuria) [L7: Bez za- } \\
\text { konye] }\end{array}$ & Drobnno (minutim) [L7: Drobno] \\
\hline $\begin{array}{l}\text { Bißnovvati (rabiare) [L7: } \\
\text { Bifsnovati] }\end{array}$ & $\begin{array}{l}\text { Dugo-xivv (longaevus) [L7: Du- } \\
\text { goxiv] }\end{array}$ \\
\hline Bitti (batuere) & Duppin (delphin) \\
\hline Bitti (pulsare) [L7: Biti] & $\begin{array}{l}\text { Dvvoyczi (gemellus) [L7: Dvoy- } \\
\text { czi] }\end{array}$ \\
\hline Bitti (verberare) & Giztinno (utique) \\
\hline $\begin{array}{l}\text { Blagodarnoftt (largitas) [L7: } \\
\text { Blagodarnoft] }\end{array}$ & Glavvan (capito) [L7: Glavan] \\
\hline C $\int a \iint a$ (calix) [L7: Clalsa] & Glavvat (capitatus) [L7: Glavat] \\
\hline C $\int a \iint a$ (crater) [L7: Clalsa] & Glivoa [U] \\
\hline Czelovv (basium) [L7: Czelov] & Gnyive (indignatio) [L7: Gnyiv] \\
\hline Czelovv (suavium) [L7: Clelov] & $\begin{array}{l}\text { Gnyivvatiße (indignari) [L7: } \\
\text { Gnyivatifse] }\end{array}$ \\
\hline $\begin{array}{l}\text { Czivv (canna) [L7: Cziv] } \\
\text { Czrikvva (aedes) [L7: Czrikva] }\end{array}$ & $\begin{array}{l}\text { Golubinny [tj. Golubinnyi] } \\
\quad \text { (columbinus) }\end{array}$ \\
\hline Danni [tj. Dannyi] (diurnus) & Gufsar (praedo) [L7: Gufsar] \\
\hline $\begin{array}{l}\text { Daslyve [tj. Daslyive] (pluvialis) } \\
\text { [L7: Daflyv] }\end{array}$ & $\begin{array}{l}\text { Guffinicza (campe) } \\
\text { Gutavv (podagricus) [L7: Gutav] }\end{array}$ \\
\hline Dafyatti (pluere) & Gyztinno (equidem) \\
\hline $\begin{array}{l}\text { Divoya-loza (labrusca) [L7: Di- } \\
\text { vya loza] }\end{array}$ & $\begin{array}{l}\text { Himmben (versutus) [L7: Him- } \\
\text { ben] }\end{array}$ \\
\hline $\begin{array}{l}\text { Divoyi (ferus) [L7: Diviy, tj. Di- } \\
\quad \text { vyi] }\end{array}$ & Hittar (agilis) \\
\hline $\begin{array}{l}\text { Divoyi-golub (palumbis) [L7: Di- } \\
\quad \text { vyi Golub] }\end{array}$ & $\begin{array}{l}\text { Hittar (pernix) } \\
\text { Hittar (rapidus) }\end{array}$ \\
\hline & Hittàr (ocyor) [L7: Hittar] \\
\hline
\end{tabular}




\begin{tabular}{|c|c|}
\hline Izbitti (aboriri) & Kuppicza (pocillum) \\
\hline $\begin{array}{l}\text { Izuviditti (scrutari) [L7: Izuvi- } \\
\text { diti] }\end{array}$ & $\begin{array}{l}\text { Kuffanye (experientia) [L7: } \\
\text { Kufsanye] }\end{array}$ \\
\hline $\begin{array}{l}\text { Izvamy [tj. Izvanny, dotično Iz- } \\
\text { vannyi] (exterus 'Iz vamy') }\end{array}$ & $\begin{array}{l}\text { Kuffanye (specimen) [L7: } \\
\text { Kufsanye] }\end{array}$ \\
\hline $\begin{array}{l}\text { Izvanny [tj. Izvannyi] (extraneus } \\
\text { 'Iz vanny') }\end{array}$ & $\begin{array}{l}\text { Kuffanye (tentamentum) [L7: } \\
\text { Kufsanye] }\end{array}$ \\
\hline Izzuti (exuere) & Ku $\int_{s a t i}$ (experiri) [L7: Kulsati] \\
\hline $\begin{array}{l}\text { Kakovvi (cuiusmodi) [L7: Kako- } \\
\text { vi] }\end{array}$ & $\begin{array}{l}\text { Kußavv (blaesus) [L7: Kufsav] } \\
\text { Kvafsina (acetum) [L7: Kvalsina] }\end{array}$ \\
\hline Karvavv (cruentus) [L7: Karvav] & Kvvaßan (austerus) [L7: Kvalsan] \\
\hline Karvv (cruor) [L7: Karv] & Lavv (leo) [L7: Lav] \\
\hline Karvo (sanguis) [L7: Karv] & Liplyvo [tj. Liplyivo] (glutinosus) \\
\hline  & [L7: Liplyv] \\
\hline  & Lippa (tilia) \\
\hline 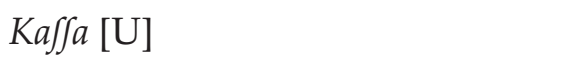 & Livo (levus) [L7: Liv] \\
\hline  & Livo (sinister) [L7: Liv] \\
\hline  & Lokvva (lacuna) [L7: Lokva] \\
\hline Koppun (capus \& capo) & Maglive (nebulosus) [L7: Ma- \\
\hline Koffara [fiscella] [L7: Kolsara] & gliv] \\
\hline Kofullya (subucula) [L7: Kolulya] & $\begin{array}{l}\text { Meftrovvzki (artificiosus) [L7: } \\
\text { Meltrovzki] }\end{array}$ \\
\hline $\begin{array}{l}\text { Кољзва[U] } \\
\text { Koßßiti [U] }\end{array}$ & Miloftive (clemens) [L7: Miloftiv] \\
\hline Krafft (virtus) [L7: nedostaje] & $\begin{array}{l}\text { Milosztive (misericors) [L7: } \\
\text { Milofztiv] }\end{array}$ \\
\hline Kralyevo (regius) [L7: Kralyov] & Mlohavv (debilis) [L7: Mloháv] \\
\hline $\begin{array}{l}\text { Kralyevoati (regnare) [L7: } \\
\text { Kraly[e]vati] }\end{array}$ & $\begin{array}{l}\text { Mlohavv (languidus) [L7: Mlo- } \\
\text { hav] }\end{array}$ \\
\hline $\begin{array}{l}\text { Kralyevv-dvor (regia) [L7: Kra- } \\
\text { lyev dvor] }\end{array}$ & $\begin{array}{l}\text { Mlohavvztvo (debilitas) [L7: Mlo- } \\
\text { havztvo] }\end{array}$ \\
\hline Krive (camurus) [L7: Kriv] & Nakovv (incus) [L7: Nakov] \\
\hline Krivv (curvus) [L7: Kriv] & Napokonny [tj. Napokonnyi] (ulti- \\
\hline Krovv (tectum) [L7: Krov] & mus) \\
\hline Krusvva [U] & Napokonyni [tj. Napokonnyi] (ex- \\
\hline Kирра (crater) & tremus) \\
\hline
\end{tabular}


Narave (natura) [L7: Narav]

nasfim [SA]

Naßlidovvati (assectari) [L7:

Na[slidovati]

Naßlidowonik (assecla) [L7:

Nalslidovnik]

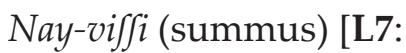

Nayvilsi]

Nepravo (falsus) [L7: Neprav]

Ne-uffanye (diffidentia) [L7:

Neuffanye]

Nezdravv (morbidus) [L7:

Nezdrav]

Obba (ambo)

Oddarth (lacer)

oddati (maritare)

Oddatiße (nubere)

Oddirati (glubere)

Odditi (amicire)

Oditti (induere)

Oglave (capistrum) [L7: Oglav]

Oppaliti (amburere)

Oppalyen (ambustus)

Oppasfati (cingere) [L7:

Oppalsati]

Oppaßan (cinctus)

Oppat (abbas)

Oppaticza [U]

Oppekà (later)

Oppet (iterum)

oppeta (recuperare ‘Dobiti-oppe-

ta') [L7: Dobiti oppeta]

Oppeta doneßti (referre)
Oppeta-poßlati (remittere) [L7:

Oppeta polslati]

Oppeth (denuò)

Oppliniti (orbare)

Oppliniti (viduare)

Oppoganiti (profanare)

Oppovijßt [= Oppoviißst] (omen)

[L7: Oppovylst]

Oprafsati (interrogare) [L7:

Opralsati]

Ottarti (abstergere)

Ottiti (abire)

Ottiti (discedere)

Ovakovv (eiusmodi) [L7: Ovakov]

Ovakovv (huiusmodi) [L7: Ovakov]

Ovvde (hic) [L7: Ovde]

Passa (pabulum) [L7: Pafsa]

Peddeßeet (quinquaginta) [L7:

Petde[set]

Pinezlyvo [t. Pinezlyivo] (pecuniosus) [L7: Pinezlyiv]

Plavv (coeruleus, tj. caeruleus)

[L7: Plav]

Plavo (navis) [L7: Plav]

Plifivo (calvus) [L7: Plifiv]

Pomnyov [tj. Pomnyivo] (dili-

gens) [L7: Pomnyv]

Pomnyov [tj. Pomnyive] (solici-

tus) [L7: Pomnyv]

Ppribigal [t. Pribigal] (perfuga)

[L7: Pribigal]

Pravv (aequus) [L7: Prav] 
Pribilfztvoo (candor) [L7:

Pribillztvo]

Pri-blixatifse (appropinquare)

[L7: Priblixatifse]

Pripafsati (accingere) [L7:

Pripalsati]

Prifsan [crudus]

Protive (adversum) [L7: Protiv]

Protive (contra) [L7: Protiv]

Protivoschina (oppositio) [L7:

Protivichina]

Prufsacz (gradarius) [L7:

Prulsacz]

Pyazza (forum)

Radovatiffe (gaudere) [L7:

Radovatifse]

Ranno (mane) [L7: nedostaje]



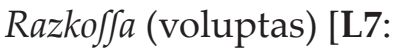

Razkolsa]

Razkoffe (deliciae) [L7: Razkolse]

Rippa (rapa)

Rippa [U]

Roffzà (ros) [L7: Rolszà]

Saffran (crocus)

Schyetta (vitium)

Seglyvo [tj. Seglyivo] (facetus)

[L7: Seglyv]

ftalla (hara 'Szvinyzka-Italla')

[L7: Szvinyzka Italla]

Szappun [U]

Szinnicza (scena)

Szinnicza (tabernaculum)

Szinnicza [U]

Szlivv (coluber) [L7: Szliv]
Szmarznutifse (congelare) [L7:

Szmarznutilse]

Szolinne (salina)

Szuprotive (obviam) [L7: Szuprotiv]

Szvag-dannyi (quotidianus) [L7:

Szagdannyi]

Szvvarfen (perfectus) [L7:

Szvarlen]

Buprotive (adversus) [L7: Szu-

protiv]

Tepavv (balbus) [L7: Tepav]

Tuxitifse (expostulare) [L7:

Tuxitilse]

Vcseranny [tj. Vcserannyi] (hesternus)

Vesfel (hilaris) [L7: VeIsel]

Vesfelye (laetitia) [L7: Velselye]

Vffanye [= Uffanye] (fidentia)

Vffanye [= Uffanye] (fiducia)

Vffati [= Uffati] (sperare)

Vffatifze [= Uffatifze] (confidere)

Vffatiße [= Uffatiße] (fidere)

Ville [U]

Villè (furca) [L7: Ville]

Visfina (statura) [L7: Virsina]

Vvenul [= Uvenul] (flaccidus)

Voran (ater)

Vvridno/zt (valor) [L7: Vridnolzt]

Vvriti (aestuare)

Vvruch (fervidus) [L7: Vruch]

Vvruchina (aestus)

Vzdarxatifse [= Uzdarxatifse] (abstinere) [L7: Vzdarxatifse]

Xarxtvvo (crapula) [L7: Xarxtvo] 
Xivv (superstes) [L7: Xiv]

Xuppan (villicus)

Yednaftvoo (aequalitas) [L7:

Yednaltvo]

Zdrave (salutaris) [L7: Zdrav]
Zdrave (sanus) [L7: Zdrav]

Zidannye (structura) [L7:

Zidanye]

Zvvir (animal, animans) [L7:

Zvìr]

Zzlo-volian [t.. Zlo-volian] (tristis)

Dva nadslovka (2 riječi različnice)

Dáár (munus) [L2: Daar]

Kàrà (controversia) [L2: Kara]

Lodereckerov hrvatsko-latinski rječnik

TUPI ZNAK (45 riječi različnica)

$\begin{array}{ll}\text { Akò } & \text { Offtrogà (calcar) } \\ \text { Bàth } & \text { Ovràth } \\ \text { Bogàth } & \text { Pifsiczè } \\ \text { Cziczà } & \text { Plemè } \\ \text { Drivò } & \text { Poglèd } \\ \text { Evò } & \text { Ranà } \\ \text { Hotè } & \text { fftranè (Navffe fftranè) } \\ \text { Kakonè } & \text { Szokòl } \\ \text { Kokòs } & \text { Szramotà } \\ \text { Kolà } & \text { Sztàn } \\ \text { Kopilò } & \text { Sztò } \\ \text { Korà } & \text { Szvità } \\ \text { Mifftò } & \text { Timè } \\ \text { Muclè } & \text { Tilztò } \\ \text { mukè (Czvit od mukè) } & \text { Tlò } \\ \text { Nayparvò } & \text { Vdò [= Udò] } \\ \text { Odondeyfftò (indidem) } & \text { Wàn } \\ \text { Okò } & \text { welè } \\ \text { Oràl } & \text { werà } \\ \text { Oftrò } & \text { widrò }\end{array}$


wunà

Yakò

Yatò

OŠTRI ZNAK (14 riječi različnica)

Kós

Ná

Navrimé

Páls

Peró

Pó

Strolák
Zà

Zarnò
Szeló

Szláb

Szvakoyakó

Vgár [= Ugár] (Ungarus)

Xaló

Yamácz

Zató

UDVOJENI SAMOGLASNICI (224 riječi različnice)

\begin{tabular}{|c|c|}
\hline Baan & Czyiv [tj. Czjiv = Cziiv $]$ \\
\hline Baaz & Czyl [tj. Czijl = Cziil $]$ \\
\hline Bahaat & Daan \\
\hline Bdechij [= Bdechii] & Daar \\
\hline Bijl [= Biil] & Darhaat \\
\hline $\operatorname{Bij}\left[s\left[=\operatorname{Bii} \int s\right]\right.$ & Deefzna \\
\hline Blaak [tj. Blaag] & Diym [tj. Dijm = Diim] \\
\hline Blijd [= Bliid $]$ & Dobyt [tj. Dobijt $=$ Dobiit $]$ \\
\hline Bludoofft [tj. Bludnoofft] & Druug \\
\hline Bluud & Duub \\
\hline Book & Duug \\
\hline Boor & Dyil [tj. Djil = Diil $]$ \\
\hline Braak & Glaad \\
\hline Brij[st [= Briifst $]$ & Glaals (fama, rumor) \\
\hline Brood & Glaalz (sonus, vox) \\
\hline Bruus & Gluuh \\
\hline Claaflt & Glyedaa \\
\hline Clelyuufft & Glyzte [= Gliizte] \\
\hline Clryip [t]. Clrjip = C〔riip] & Gnyzdo [= Gniizdo] \\
\hline Czvijt [= Czviit $]$ & Gool \\
\hline
\end{tabular}




\begin{tabular}{|c|c|}
\hline Goozt & Maal \\
\hline Graad & Meed \\
\hline Gullaar & Meutoo \\
\hline Guulft & Mij [= Mii] \\
\hline Hchij [= Hchii] & Mijh [= Miih] \\
\hline Hebaath (ebulum) & Mlaad \\
\hline Hijt [= Hiit $]$ & Mlaak \\
\hline Hnopoot [tj. Hropoot] & Mladoofft \\
\hline Huud & Mnoog \\
\hline Izboor & Mooch \\
\hline Kneez & Mraak \\
\hline Koofz & Muuka (farina) \\
\hline Krijx $[=$ Kriix $]$ & Muux \\
\hline Kruug & Myr [tj. Mijr = Miir $]$ \\
\hline Kvaar & Naduut \\
\hline Kyip [tj. Kjip = Kiip] & Nazaad \\
\hline Laan & Nellpoor \\
\hline Laaxacz & Nooch \\
\hline Leed & Nools \\
\hline Lijk [= Liik] & Noox \\
\hline Lijn [= Liin] & Nymac [= Niimac] \\
\hline Lijp [= Liip] & Nymska [= Niimska] (Nymska \\
\hline Lijft $[=$ Liift $]$ & Zemle) \\
\hline Livaa & Nym flky [= Niim Ifkii] \\
\hline Ludoolzth & Obiknuut \\
\hline Luucs & Oblaak \\
\hline Luud & Obruulz \\
\hline Luugh & Oon \\
\hline Luuk & Oppovij[st [= Oppoviifst] \\
\hline Lyip [tj. Ljip = Liip] (gluten) & Ovclaar \\
\hline lyifft [tj. ljifft = liif $\left.\int \mathrm{t}\right]$ (wernyi & Paah \\
\hline lyi( (रt) & Paaka \\
\hline Lyuut & Paals \\
\hline
\end{tabular}




\begin{tabular}{|c|c|}
\hline Pameet & Ruub \\
\hline Peech & Ruud \\
\hline Peeflt & Ruuh \\
\hline Peet & Ruun \\
\hline Petdelleet & Ruulz \\
\hline Petij [= Petii $]$ & Ryz [tj. Rijz = Riiz] \\
\hline Pet爪ltoo & Saala \\
\hline Pijr [= Piir $]$ & Schijt [= Schiit $]$ \\
\hline Piyaat [tj. Priyaat] & Selz $[\mathrm{t}]$ [ztoo \\
\hline Plijn [= Pliin $]$ & Sijs [= Siis] \\
\hline Plijfs [= Pliifs] & Strijcz [= Striicz $]$ \\
\hline Plood & Ity [tj. Itij = Itii] (Koyi Ity) \\
\hline Ploot & Szaad \\
\hline Pomaafzt & Szaag \\
\hline Pool & Szaam \\
\hline Pooloviti & Szaan \\
\hline Poolsth & Szalaa[zt [tj. Szlaa[zt] (sapor) \\
\hline Poot & Szedamlztoo \\
\hline Poflluuh & Szijd [= Sziid] \\
\hline Praach & Szijk [= Sziik] \\
\hline Praah & Szijn [= Sziin] \\
\hline Praaz & Szijr [= Sziir $]$ \\
\hline Praazdnofft & Szlaaflth (dulcedo, iucunditas) \\
\hline Prateex & Szmook \\
\hline Pruuth & Szmrycs [= Szmriics] (iuniperus) \\
\hline Puuk & Szook \\
\hline Puuth & Szpoor \\
\hline Raath & Szpravee (serio) \\
\hline Raax & Szraam \\
\hline Razboor & Szrijs [= Szriis] (muscus) \\
\hline Reezti & Sztijd [= Sztiid] \\
\hline Rijcs [= Riics] & Sztool \\
\hline Rood & Sztraah \\
\hline
\end{tabular}




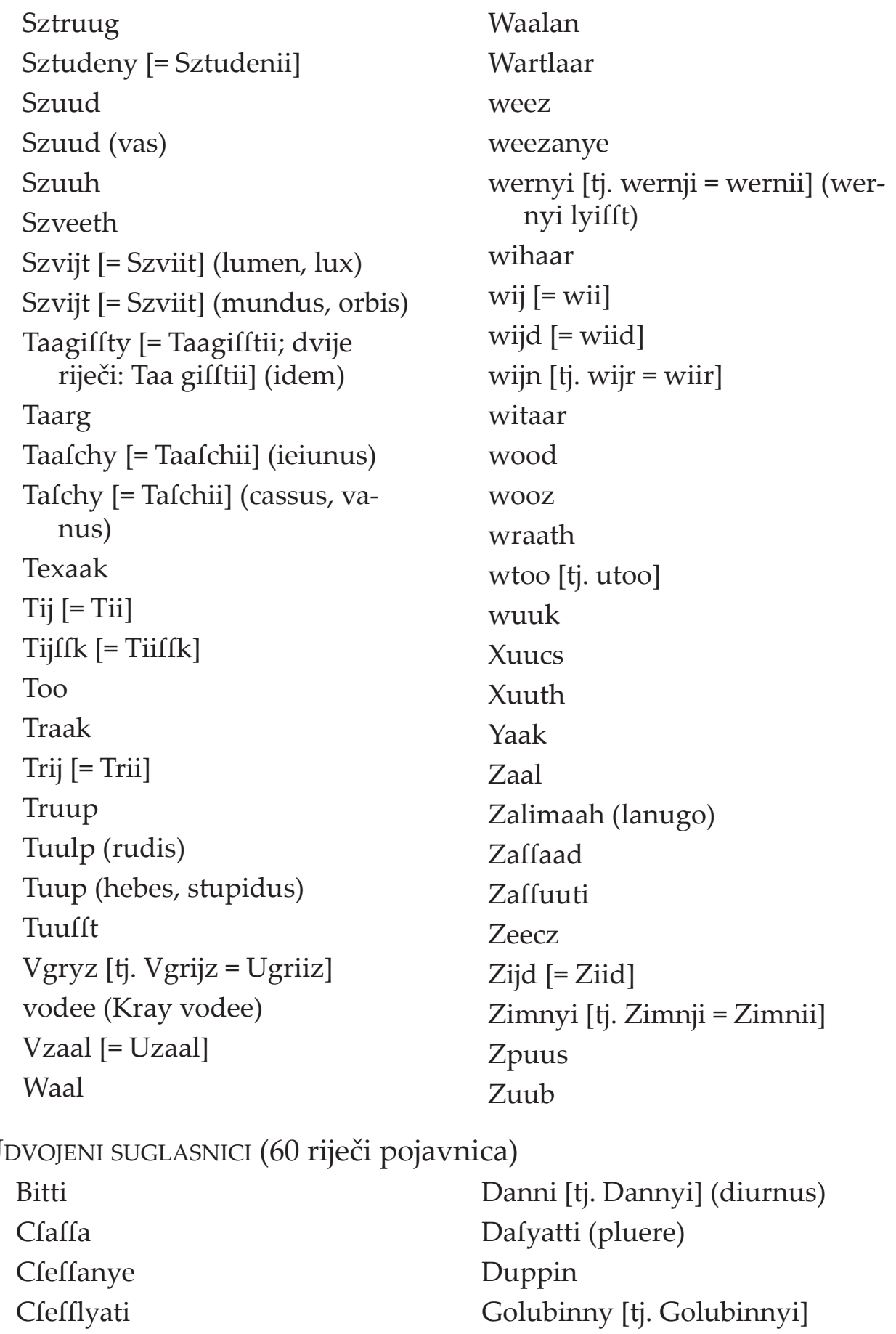




\begin{tabular}{|c|c|}
\hline Gyztinno (equidem) & Oppalfati \\
\hline Hittar & Oppat \\
\hline Izbitti & Oppeka \\
\hline Izvanny [tj. Izvannyi] & oppeta (Dobiti oppeta) \\
\hline Izzuti & Oppeth \\
\hline Kalla & Oppliniti \\
\hline Kaffaly & Oppoganiti \\
\hline Kalllyati & Oppovij[st [= Oppovii[st] \\
\hline Koppun & Opraflati \\
\hline Koflara & Ottarti \\
\hline Kuppa & Ottiti \\
\hline Kuppicza & Palla \\
\hline Kullanye & Pyazza \\
\hline Kuflati & Rippa \\
\hline Neuffanye & Saffran \\
\hline Obba & Szinnicza (tabernaculum, um- \\
\hline Oddarth (lacer) & braculum) \\
\hline Oddati & Szinnicza (scena) \\
\hline Oddatifle & Szolinne \\
\hline Oddavna & Vffanye [= Uffanye] \\
\hline Oddila [= Od dila] (particeps) & Vffati [= Uffati] \\
\hline Oddirati (glubere) & Vffatille [= Uffatille] \\
\hline Odditi & Vvenul [= Uvenul] \\
\hline Okuflenye & Vvrime [= Uvrime] \\
\hline Oppaliti & wcleranny [tj. wclerannyi] \\
\hline Oppalyen & Yednalftvo \\
\hline Oppalfan & \\
\hline
\end{tabular}




\section{Popis uporabljenih djela ${ }^{55}$}

Babukić, Vjekoslav. Ilirska slovnica / sastavi Věkoslav Babukić. U Zagrebu : Bèrzotiskom nar. tiskarnice Dra. Ljudevita Gaja, 1854.

Bezlaj, France. Etimološki slovar slovenskega jezika. Ljubljana : Slovenska akademija znanosti in umetnosti ; Inštitut za slovenski jezik, 19762005. 4 sv.

Birnbaum, Marianna D. Ambrogio Calepino i Faust Vrančić. // Zbornik o Faustu Vrančiću : zbornik radova sa znanstvenog skupa Obitelj Vrančić u hrvatskoj književnosti i znanosti : Šibenik, 12.-14. rujna 1995. Šibenik : Gradska knjižnica »Juraj Šižgorić«, 2001. Str. 31-35. [Knjižnica Faust.]

Bratulić, Josip. Faust Vrančić, književnik i hagiograf / Josip Bratulić. // Život nikoliko izabranih divic / Faust Vrančić ; priredili Josip Bratulić, Branimir Glavičić, Josip Lisac, Mirjana Šokota. Šibenik : Gradska knjižnica »uraj Šižgorić«, 1995. Str. 123-144. [Knjižnica Bašćina.]

Brlić, Ignjat Alojzije. Grammatik der illirischen Sprache, wie solche in den südslawischen Ländern Serbien, Bosnien, Slavonien, Dalmatien, Kroatien und von den Illiriern und Serben in Ungarn und der Vojvodina gesprochen wird / für Deutsche verfaßt und herausgegeben von Ignatz Al. Berlić. 3. durchgesehene und verbesserte Auflage. Agram : Gedruckt und im Verlage bei Franz Suppan, k. k. pr. Buchdrucker und Buchhändler, 1850. [Got.]

Broz, Ivan ; Iveković, Franjo. Rječnik hrvatskoga jezika / skupili i obradili Dr. F. Iveković i Dr. Ivan Broz. U Zagrebu : Štamparija Karla Albrechta (Jos. Wittasek), 1901. 2 sv.

Cronia, Arturo. Contributo alla lessicografia serbo-croata : un'inedita redazione trilingue del »Dictionarium quinque nobilissimarum Europae linguarum « di Fausto Veranzio / Arturo Cronia. // Ricerche slavistiche : [pubblicazione dell'Istituto di filologia slava dell'Università di Roma, dell'Istituto per l'Europa orientale di Roma e del Seminario di slavistica dell'Istituto universitario orientale di Napoli / a cura di Giovanni Maver]. Vol. 2 (1953) ; str. 117-130.

Daničić, Đuro. Prilog za istoriju akcentuacije hrvatske ili srpske / čitao u sjednici filologičko-historičkoga razreda jugoslavenske akademije znanosti i umjetnosti 10 travnja 1872 pravi član dr. Gjuro Daničić. // Rad Jugoslavenske akademije znanosti i umjetnosti. (1872), knj. 20 ; str. 150-233.

Della Bella, Ardelio. Istruzioni grammaticali della lingua illirica = Gramatičke pouke o ilirskome jeziku / prijevod s izvornika Nives Sironić-Bonefačić ;

55 U ovom se članku zapisi bibliografskih jedinica iznimno donose prema sustavu koji je postavio autor, a koji u pojedinim točkama odudara od sustava koji se inače primjenjuje u Filologiji. 
pogovor Darija Gabrić-Bagarić. Zagreb : Institut za hrvatski jezik i jezikoslovlje, 2006. [Biblioteka Pretisci ; knj. 6.]

Dugački, Vladimir. Hrvatsko medicinsko nazivlje u Dikcionaru Fausta Vrančića. // Zbornik o Faustu Vrančiću : zbornik radova sa znanstvenog skupa Obitelj Vrančić u hrvatskoj književnosti i znanosti : Šibenik, 12. 14. rujna 1995. Šibenik : Gradska knjižnica »Juraj Šižgorić«, 2001. Str. 23-29. [Knjižnica Faust.]

Dukat, Vladoje. Rječnik Fausta Vrančića / napisao član dopisnik Vladoje Dukat ; primljeno u sjednici razreda historičko-filologičkoga od 18. maja 1924. // Rad Jugoslavenske akademije znanosti i umjetnosti. (1925), knj. 231 ; str. 102-136. Razreda historičko-filologičkoga i filozofičko-juridičkoga ; knj. 101.

Fazekas, Emese. Petojezični rječnik Fausta Vrančića, jedna od proih jezikoslovnih riznica. // Zbornik o Faustu Vrančiću : zbornik radova sa znanstvenog skupa Obitelj Vrančić u hrvatskoj književnosti i znanosti : Šibenik, 12. 14. rujna 1995. Šibenik : Gradska knjižnica »Juraj Šižgorić«, 2001. Str. 37-43. [Knjižnica Faust.]

Finka, Božidar. Čakavsko narječje. // Čakavska rič : polugodišnjak za proučavanje hrvatske čakavske riječi. God. 1 (1971), br. 1 ; str. 11-71.

Garde, Paul. Naglasak / prevoditelj Dragutin Raguž. Zagreb : Školska knjiga, 1993.

Gostl, Igor. Od poredbenog jezičnog kompendija Fausta Vrančića do osmerojezičnog enciklopedijskog rječnika : Jugoslavenski leksikografski zavod u kontekstu suvremene leksikografije. // Informatologia Yugoslavica : [službeno glasilo Referalnog centra Sveučilišta u Zagrebu = official journal of the Referral Centre of the University of Zagreb]. God. 16 (1984), br. 3-4 ; str. 263-268.

Gyurikovits, Georgius. Biographia Fausti Verantii, Secretarii et Consiliarii Regii, Episcopi Chanadiensis / Georgius Gyurikovits. // Dictionarium pentaglottum / recudi curavit Josephus Thewrewk de Ponor. Posonii : Typis Belnayanis, 1834. Str. IX-XX.

Hamm, Josip. Prosodijski sistem Križanićeva govora. // Život i djelo Jurja Križanića : zbornik radova. Zagreb : Fakultet političkih nauka Sveučilišta u Zagrebu ; Izdavački servis Liber, 1974. Str. 212-238. [Biblioteka Politička misao.]

Hamm, Josip ; Hraste, Mate ; Guberina, Petar. Govor otoka Suska. // Hrvatski dijalektološki zbornik. (1956), knj. 1; str. 7-213.

Hjelmslev, Louis. Accent, intonation, quantité / Louis Hjelmslev. // Studi baltici / a cura di Giacomo Devoto, Professore nella R. Università di Firenze. (1936-1937), vol. 6 ; str. 1-57. [Publicazioni dell' « Istituto per l'Europa orientale » Roma. Sezione baltica ; knj. 6.] 
Hraste, Mate. Čakavski dijalekat ostrva Hvara / Mate M. Hraste. // Južnoslovenski filolog : povremeni spis za slovensku filologiju i lingvistiku. (1935), knj. 14 ; str. $1-57$.

Hraste, Mate. Čakavski dijalekat ostrva Brača / od Dr-a Mate M. Hraste. // Srpski dijalektološki zbornik : rasprave i građa. (1940), knj. 10 ; str. 1-67.

Hraste, Mate. O kanovačkom akcentu u Hrvatskoj / (primljeno za Filologiju na 2. sjednici V. odjela od 6. III. 1956.). // Filologija. (1957), knj. 1, str. $59-75$.

Hraste, Mate. Osnovna akcentuacija Biograda na moru i njegove okolice. // Filologija. (1959), knj. 2 ; str. 5-11.

Hraste, Mate ; Šimunović, Petar ; Olesch, Reinhold. Čakavisch-deutsches Lexikon / von Mate Hraste und Petar Šimunović ; unter Mitarbeit und Redaktion von Reinhold Olesch. Teil 1. Köln ; Wien : Böhlau Verlag, 1979. [Slavistische Forschungen / herausgegeben von Reinhold Olesch; Band 25/1.]

Ivšić, Stjepan. Prilog za slavenski akcenat / primljeno u sjednici historičko-filologičkoga razreda Jugoslavenske akademije znanosti i umjetnosti dne 10. maja 1910. ; napisao Stjepan Ivšić. // Rad Jugoslavenske akademije znanosti i umjetnosti. (1911), knj. 187 ; str. 133-208. Razredi historičko-filologički i filozofičko-juridički ; knj. 77.

Ivšić, Stjepan. Slavenska poredbena gramatika / priredili Josip Vrana i Radoslav Katičić ; [kazala izradio Dubravko Škiljan]. Zagreb : Školska knjiga, 1970.

Ivšić, Stjepan. Izabrana djela iz slavenske akcentuacije = Gesammelte Schriften zum slavischen Akzent / mit einer Einleitung sowie Berichtigungen und Ergänzungen des Verfassers herausgegeben von Christiaan Alphonsus van der Berk. München : Wilhelm Fink Verlag, 1971. [Slavische Propyläen : Texte in Neu- und Nachdrucken ; Band 96.]

Jonke, Ljudevit. »Dikcionar« Fausta Vrančića. // Dictionarium quinque nobilissimarum Europae linguarum, Latinae, Italicae, Germanicae, Dalmati[c]ae, \& Ungaricae / [Faust Vrančić]. Venetiis : Apud Nicolaum Morettum, 1595. [Pretisak. 6. izd. Zagreb : Novi Liber, 1992. Str. 135139.]

Junković, Zvonimir. Prilog za suvremenu čakavsku dijalektologiju. //Čakavska rič : polugodišnjak za proučavanje čakavske riječi. God. 3 (1973), br. 1 ; str. $7-38$.

Jurišić, Blaž. Rječnik govora otoka Vrgade. Zagreb : Jugoslavenska akademija znanosti i umjetnosti, 1966. Dio 1: Uvod. [Biblioteka Hrvatskog dijalektološkog zbornika.] 
Jurišić, Blaž. Rječnik govora otoka Vrgade : uspoređen s nekim čakavskim i zapadnoštokavskim govorima. Zagreb : Jugoslavenska akademija znanosti i umjetnosti, 1973. Dio 2: Rječnik. [Biblioteka Hrvatskoga dijalektološkog zbornika ; knj. 1, dio 2.]

Jurišić, Blaž. Nacrt hrvatske slovnice : glasovi i oblici u povijesnom razvoju. Zagreb : Matica hrvatska, 1992. [Pretisak izdanja iz 1944.] [Znanstvena knjižnica.]

Jurišić, Blaž. Nacrt hrvatske slovnice : tvorba imenica u povijesnom razvoju. Zagreb : Matica hrvatska, 1992. [Znanstvena knjižnica.]

Karadžić, Vuk Stefanović. Srpski rječnik, istolkovan njemačkim i latinskim riječima / skupio ga i na svijet izdao Vuk Stefanović = Wolf Stephansohn's Serbisch-Deutsch-Lateinisches Woerterbuch = Lupi Stephani F. Lexicon Serbico-Germanico-Latinum. U Beču (Wien, Viennae) : Gedruckt bei den P. P. Armeniern, 1818. [Ćir.]

Karadžić, Vuk Stefanović. Srpski rječnik istumačen njemačkijem i latinskijem riječima / skupio ga i na svijet izdao Vuk Stef. Karadžić = [Lexicon Serbico-Germanico-Latinum / edidit Vuk Steph. Karadschitsch]. U Beču : U štampariji jermenskoga manastira $=[$ Vindobonae $:$ Typis Congregationis Mechitaristicae], 1852. [Ćir.]

Kašić, Bartol. Institutionum linguae Illyricae libri duo / authore Bartholomaeo Cassio Curictensi Societatis Iesu. Ed. 1. Romae : Apud Aloysium Zannettum, 1604. // Most = The bridge : a journal of Croatian literature ; Collection of Croatian literature. (1990), sv. 1 ; str. 237-427. [Pretisak.]

Kašić, Bartol. Osnove ilirskoga jezika u dvije knjige / autor Bartol Kašić Pažanin Družbe Isusove ; [prijevod s izvornika Sanja Perić Gavrančić] $=[$ Institutionum linguae Illyricae libri duo / authore Bartholomaeo Cassio Curictensi Societatis Iesu]. 1. izd. Zagreb : Institut za hrvatski jezik i jezikoslovlje, [2002]. [Biblioteka Pretisci ; knj. 1.] [Pretisak izd. U Rimu : kod Alojzija Zannettija, 1604. = Romae : Apud Aloysium Zannettum, 1604.]

Katičić, Radoslav. Lodereckerov rječnik - leksikografsko djelo i kulturni spomenik = Lodereckerũo slowník - lexikografické dílo a kulturní památka. // Sedmerojezični rječnik : prvotisak, Prag 1605. : pretisak i Dodatak, Zagreb 2005. / Petar Loderecker = Sedmijaziční slovník : první vydaní Praha 1605 : reprint a Dodatek, Záhřeb 2005 / Petr Loderecker. Zagreb : Novi Liber ; Nacionalna i sveučilišna knjižnica, 2005. Str. 16-49. [Serija reprint izdanja Liber Croaticus.]

Klaić, Bratoljub. Jedan pedagoški pokušaj u akcentologiji. // Zbornik u čast Stjepana Ivšića $=$ [Collectanea in Stephani Ivšić honorem] / [urednici Mate Hraste, Ljudevit Jonke, Milan Ratković]. Zagreb : Hrvatsko filološko društvo, 1963. Str. 195-202. 
Klaić, Bratoljub. Bizovačko narječje / Adolf Bratoljub Klaić. Bizovac : Matica hrvatska, Ogranak Bizovac, 2007.

Klaić, Bratoljub. Naglasni sustav standardnoga hrvatskog jezika / izvorni rukopis uredio Božidar Smiljanić. Zagreb : Nova knjiga Rast d.o.o., 2013.

Knežević, Petar. Pisme duhòvnè ràzlikè / sastavgljene od O. F. Petra Knèxevichia iz Knìna rèda S. O. Francescka od obslùxènja, a Provìnciè Prisvètòga Odkùpiteglja u Dalmàcii. Ù Mletczìh : Pò Scimunu Occhi, 1765.

Kortlandt, F[rederik] H[erman] H[enri]. Slavic accentuation : a study in relative chronology / F. H. H. Kortlandt. Lisse, Netherlands : The Peter de Ridder Press, 1975. [PdR Press Publications in SLAVIC ACCENTUATION ; knj. 1.]

Kortlandt, Frederik Herman Henri. From Serbo-Croatian to Indo-European / Frederik Kortlandt. // Wiener Slavistisches Jahrbuch. (2005), Band 51 ; str. $113-130$.

Krstić, Kruno. Latinica : kod Hrvata. // Enciklopedija Jugoslavije. Zagreb : Izdanje i naklada Leksikografskog zavoda FNRJ, 1962. Sv. 5. Str. 476477.

László, Bulcsú (a). Bilježka o_književnōme naglasku hrvātskōme. // Suvremena lingvistika. God. 22 (1996), sv. 1-2 (br. 41-42) ; str. 333-391.

László, Bulcsú (b). Općitbena bilježitost pri odredbi srbštine $i$ hrvatštine. // Jezik i komunikacija : zbornik / urednici Marin Andrijašević, Lovorka Zergollern-Miletić. Zagreb : Hrvatsko društvo za primijenjenu lingvistiku, 1996. Str. 430-451.

László, Bulcsú. Jèz'ikovnīk : rjèčn'īk b'îrānīh ríečìih. [Neobjavljeni rukopis.]

Lisac, Josip. Hrvatski jezik i Faust Vrančić, s osobitim obzirom na Život nikoliko izabranih divic / Josip Lisac. // Život nikoliko izabranih divic / Faust Vrančić ; priredili Josip Bratulić, Branimir Glavičić, Josip Lisac, Mirjana Šokota. Šibenik : Gradska knjižnica »Juraj Šižgorić«, 1995. Str. 145-164. [Knjižnica Bašćina.]

Lisac, Josip. Hrvatska dijalektologija. Zagreb : Golden marketing ; Tehnička knjiga, 2003. Dio 1: Hrvatski dijalekti i govori štokavskog narječja i hrvatski govori torlačkog narječja.

Lisac, Josip. Faust Vrančić i drugi : jezičnopovijesni ogledi. Šibenik : Gradska knjižnica »Juraj Šižgorić«, 2004. [Knjižnica Faust.]

Lisac, Josip. Hrvatska dijalektologija. Zagreb : Golden marketing-Tehnička knjiga, 2009. Dio 2: Čakavsko narječje.

Lisac, Josip. Hrvatski dijalekti ranoga novovjekovlja : in memoriam prof. Daliboru Brozoviću. // Dubrovnik : časopis za književnost i znanost. Nova serija, god. 22 (2011), br. 1 ; str. 226-241. 
Loderecker, Petr. Dictionarium septem diversarum linguarum, videlicet Latine, Italice, Dalmatice, Bohemicè, Polonicè, Germanicè, E Ungaricè, unà cum cuiuslibet linguae registro sive repertorio vernaculo, in quo candidus lector, sui idiomatis vocabulum, facilè invenire poterit / singulari studio \& industria collectum a Petro Lodereckero Prageno, Bohemo, \&c. Pragae : E Typographaeo Ottmariano, 1605.

Loderecker, Petr. Sedmerojezični rječnik : prootisak, Prag 1605. : pretisak i Dodatak, Zagreb 2005. / Petar Loderecker = Sedmijaziční slovník : proní vydaní Praha 1605 : reprint a Dodatek, Záhřeb 2005 / Petr Loderecker. Zagreb: Novi Liber ; Nacionalna i sveučilišna knjižnica, 2005. [Serija reprint izdanja Liber Croaticus.]

Lukežić, Iva. Prilog čitanju Della Bellinih znakova za akcente. // Filologija : [časopis Razreda za filološke znanosti Hrvatske akademije znanosti i umjetnosti]. (1991), knj. 19 ; str. 37-43.

Maretić, Tomo. Istorija hrvatskoga pravopisa latinskijem slovima / napisao Dr. T. Maretić. // U Zagrebu : U knjižarnici Jug. akademije L. Hartmana (Kugli i Deutsch), 1889. [Djela Jugoslavenske akademije znanosti i umjetnosti $=$ Opera Academiae scientiarum et artium Slavorum Meridionalium ; knj. 9.]

Marotti, Bojan. Kako je priređen Vitezovićev Lexicon Latino-Illyricum. // Lexicon Latino-Illyricum / Pavao Ritter Vitezović. Zagreb : ArTresor naklada, 2010. Sv. 2: Prijepis i obrada / rukopis kritički pročitale i rječnik upisale Zrnka Meštrović, Nada Vajs ; priredio i predgovor napisao Bojan Marotti. Str. V-CL. [Oživljena baština ; knj. 4, sv. 2.]

Marotti, Bojan. Značenje nadslovaka u Vitezovićevu Lexiconu / proslov Radoslav Katičić. Zagreb : ArTresor naklada, 2013. Sv. 1: Opći dio (opis) ; Prilozi latinski. [Raspon; knj. 1, sv. 1.]

Marotti, Bojan. Značenje nadslovaka u Vitezovićevu Lexiconu. Zagreb : ArTresor naklada, 2013. Sv. 2: Prilozi hrvatski. [Raspon ; knj. 1, sv. 2.]

Marotti, Bojan. Uvod u Vitezovićev Lexicon Latino-Illyricum. Zagreb : ArTresor naklada, 2014. [Raspon ; knj. 2.]

Matasović, Ranko. Poredbenopovijesna gramatika hrvatskoga jezika. Zagreb :

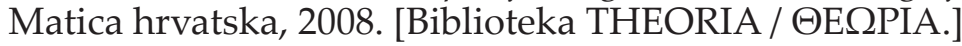

Mažuranić, Antun. Slovnica Hèrvatska : za gimnazije i realne škole / napisao Antun Mažuranić, učitelj gimn. u Zagrebu. Dio 1: Rěčoslovje. U Zagrebu : Troškom spisateljevim, 1859.

Melich, János. A magyar szótárirodalom : (negyedik közlemény) / János Melich. // Nyelvtudományi Közlemények : A Magyar Tudományos Akadémia Nyelvtudományi Bizottságának Megbizásából / szerkeszti Szinnyei József. Kötet 36 (1906), füzet 2 ; str. 165-206. 
Moguš, Milan. Današnji senjski govor / Dr Milan Moguš. // Senjski zbornik: [prilozi za geografiju, etnologiju, ekonomiku, povijest i kulturu] $=[\mathrm{Al}-$ manacco di Senj : contributi per la geografia, l'etnologia, la storia e la cultura]. God. 2 (1966) ; str. 5-152.

Moguš, Milan. Fonološki razvoj hrvatskoga jezika. Zagreb : Matica hrvatska, 1971. [Biblioteka Znanje.]

Moguš, Milan. O jedinstvu čakavske akcentuacije. // Radovi Zavoda za slavensku filologiju. (1971), knj. 12 ; str. 7-12.

Moguš, Milan. Čakavsko narječje : fonologija. Zagreb : Školska knjiga, 1977.

Moguš, Milan. Povijest hrvatskoga književnoga jezika. 2. prošireno izd. Zagreb : Nakladni zavod Globus, 1995. [Biblioteka Posebna izdanja.]

Moguš, Milan. Senjski rječnik. Zagreb : Hrvatska akademija znanosti i umjetnosti ; Senj : Matica hrvatska Senj, 2002.

Moguš, Milan ; Vončina, Josip. Latinica u Hrvata. // Radovi Zavoda za slavensku filologiju. (1969), knj. 11 ; str. 61-81.

Mrnavić, Ivan Tomko. Govor na pogrebu Fausta Vrančića / s latinskoga prevela dr. Olga Perić. Šibenik : Gradska knjižnica »Juraj Šižgorić«, 1993. [Knjižnica Bašćina.]

Mulić, Malik. Pregled ruske i srpskohrvatske akcentuacije / Dr Malik I. Mulić ; prevela Marija Mulić. 1. izd. Sarajevo : Veselin Masleša, 1985. [Biblioteka univerzitetskih udžbenika i priručnika.] [Ćir.]

Muljević, Vladimir. Tehnička terminologija u Machinae novae $i$ Dictionaru Fausta Vrančića. // Zbornik o Faustu Vrančiću : zbornik radova sa znanstvenog skupa Obitelj Vrančić u hrvatskoj književnosti i znanosti : Šibenik, 12. - 14. rujna 1995. Šibenik : Gradska knjižnica »Juraj Šižgorić«, 2001. Str. 15-22. [Knjižnica Faust.]

Musulin, Stjepan. Hrvatska i srpska leksikografija. // Filologija. (1959), knj. 2; str. $41-63$.

Pavić, Armin. Ivan Tomko Mrnavić / čitao u sjednici filologičko-historičkoga razreda jugoslavenske akademije znanosti i umjetnosti 5. svibnja 1875 pravi član Armin Pavić. // Rad Jugoslavenske akademije znanosti i umjetnosti. (1875), knj. 33; str. 58-127.

Putanec, Valentin. Dva priloga za našu bibliografiju: I. O Vrančićevu rječniku : II. O proom časopisu u Hrvatskoj »Ephemerides Zagrabiensis« ili »Nova Latina« / Dr. Valentin Putanec. // Građa za povijest književnosti hrvatske. (1951), knj. 21 ; str. 255-261.

Putanec, Valentin. Apostile uz »Dictionarium quinque nobilissimarum Europae linguarum « (1595) Fausta Vrančića. // Čakavska rič : polugodišnjak za proučavanje čakavske riječi. God. 1 (1971), br. 2 ; str. 5-18. 
Putanec, Valentin. Pogovor. // Dictionarium quinque nobilissimarum Europae linguarum, Latinae, Italicae, Germanicae, Dalmati[c]ae, \& Ungaricae / [Faust Vrančić]. Venetiis : Apud Nicolaum Morettum, 1595. [Pretisak. 6. izd. Zagreb : Novi Liber, 1992. Str. 197-198.]

Putanec, Valentin. Faust Vrančić (1551-1617) kao leksikograf. // Encyclopaedia moderna. God. 14 (1993), sv. 2 (br. 42) ; str. 144-149.

Rječnik hrvatskoga ili srpskoga jezika / na svijet izdaje Jugoslavenska akademija znanosti i umjetnosti. Zagreb : Jugoslavenska akademija znanosti i umjetnosti, $1880-1976.23 \mathrm{sv}$.

Samardžija, Marko. Hrvatski jezik u rječnicima F. Vrančića i P. Lodereckera = Charvátština ve Vrančićově a Lodereckerově slovniku. // Sedmerojezični rječnik : prvotisak, Prag 1605. : pretisak i Dodatak, Zagreb 2005. / Petar Loderecker $=$ Sedmijaziční slovník : první vydaní Praha 1605 : reprint a Dodatek, Záhřeb 2005 / Petr Loderecker. Zagreb : Novi Liber ; Nacionalna i sveučilišna knjižnica, 2005. Str. 50-75. [Serija reprint izdanja Liber Croaticus.]

Starčević, Šime. Nòvà ricsôslovica ilìricskà : vojnicskoj mladosti krajicsnoj poklonjena / trúdom i nástojànjem Shíme Starcsevicha xupnika od Novoga u Líci. U Tarstu : Slovima Gaspara Weis, 1812. [Pretisak. Zagreb : Institut za hrvatski jezik i jezikoslovlje, 2002.] [Biblioteka Pretisci ; knj. 2.]

Šimunović, Petar. Rječnik bračkih čakavskih govora. 2. dopunjeno i popravljeno izd. Zagreb : Golden marketing-Tehnička knjiga, 2009. [Izabrana djela / Petar Simunović ; knj. 4.]

Šonje, Jure [glavni urednik]. Rječnik hrvatskoga jezika. Zagreb : Leksikografski zavod Miroslav Krleža; Śkolska knjiga, 2000.

Thewrewk, József. Dictionarium pentaglottum / recudi curavit Josephus Thewrewk de Ponor. Posonii : Typis Belnayanis, 1834.

Vitezović, Pavao Ritter. Lexicon Latino-Illyricum. Zagreb : ArTresor naklada, 2000. Sv. 1: Prijeslik rukopisa / priredio i pogovor o prijesliku napisao Bojan Marotti. [Oživljena baština ; knj. 4, sv. 1.]

Vitezović, Pavao Ritter. Lexicon Latino-Illyricum. Zagreb : ArTresor naklada, 2010. Sv. 2: Prijepis i obrada / rukopis kritički pročitale i rječnik upisale Zrnka Meštrović, Nada Vajs ; priredio i predgovor napisao Bojan Marotti. [Oživljena baština ; knj. 4, sv. 2.]

Vitezović, Pavao Ritter. Lexicon Latino-Illyricum. Zagreb : ArTresor naklada ; Institut za hrvatski jezik i jezikoslovlje, 2009. Sv. 3: Hrvatsko-latinski rječnik / priredile i pogovor napisale Nada Vajs, Zrnka Meštrović. [Oživljena baština ; knj. 4, sv. 3. Rječnici hrvatskoga jezika ; knj. 6.]

Vončina, Josip. Vrančićev rječnik. // Filologija : [časopis Razreda za filologiju Jugoslavenske akademije znanosti i umjetnosti u Zagrebu]. (1979), knj. 9 ; str. $7-36$. 
Vončina, Josip. Tekstološka načela za pisanu baštinu hrvatskoga jezičnog izraza : posebni prilog Stoljećima hrvatske književnosti. Zagreb : Matica hrvatska, 1999. [Stoljeća hrvatske književnosti.]

[Vrančić, Faust.] Dictionarium quinque nobilissimarum Europae linguarum, Latinae, Italicae, Germanicae, Dalmati[c]ae, \& Ungaricae. Venetiis : Apud Nicolaum Morettum, 1595. [Pretisak. 6. izd. Zagreb : Novi Liber, 1992.]

Vrančić, Faust. Xivvot nikoliko izabraniih divviicz / pò Fauftu Vvrancsichyu Bizkupu Csanadzkomu, Vvichniku Czelzarovu iztumacseen. Romae : Apud Aloifium Zannettum, 1606. [Pretisak. Šibenik : Gradska knjižnica "Juraj Šižgorić«, 1995.]

Vrančić, Faust. Hrvatsko-latinski rječnik : 1595 / postupkom obrata izradio i pogovor napisao Valentin Putanec. 2. izd. Zagreb : Novi Liber, 1992. Str. 141-198. // Dictionarium quinque nobilissimarum Europae linguarum, Latinae, Italicae, Germanicae, Dalmati[c]ae, \& Ungaricae / [Faust Vrančić]. Venetiis : Apud Nicolaum Morettum, 1595. [Pretisak. 6. izd. Zagreb : Novi Liber, 1992.]

Vrančić, Faust. Život nikoliko izabranih divic / priredili Josip Bratulić, Branimir Glavičić, Josip Lisac, Mirjana Šokota. Šibenik : Gradska knjižnica »Juraj Šižgorić«, 1995. [Knjižnica Bašćina.]

Vukušić, Stjepan ; Zoričić, Ivan ; Grasselli-Vukušić, Marija. Naglasak u hrvatskome književnom jeziku. Zagreb : Nakladni zavod Globus, 2007. [Velika hrvatska gramatika ; knj. 4.] [Biblioteka Jezični priručnici.] 


\title{
On the Signs Above the Letters on Croatian Words in Vrančić's Dictionary
}

\begin{abstract}
In his five-language dictionary, Dictionarium quinque nobilissimarum Europae linguarum, published in Venice (1595), Croatian polymath, inventor, and lexicographer Faust Vrančić (1551-1617), while recording Croatian words, occasionally used signs above the letters. He used three signs - acute, gravis, and circumflex - inherited from Greek grammars. This paper analyzes all Croatian words which are in Vrančićs dictionary marked by one of them. An attempt was made to understand the "meaning" of those signs, i.e. to discern whether in Vrančićs dictionary they are used consistently (invariably). This turning out to be the case, another issue appeared, concerning the possibility of a description of the accent system which had to be (or could have been) recorded by those signs. The analysis was conducted strictly within the corpus of the marked words, considering only their mutual relations, i.e. not examining the so called "comparative material" taken from some Croatian dialects (Putanec). The analysis, however, showed that such a description could not be done - even when the doubling of vowels and consonants in some Croatian words was taken into account - due to the unstable (variable) usage of the three signs. The Appendix contains a list of all marked words from Vrančićs dictionary, as well as the comparison with respective examples from Loderecker's Dictionarium septem diversarum linguarum (1605).

Ključne riječi: Faust Vrančić, prozodija, tupi znak, oštri znak, zavinuti znak, kratkosilazni naglasak, visokouzlazni naglasak, dugosilazni naglasak

Keywords: Faust Vrančić, prosody, gravis, acute, circumflex, short-falling accent, high-rising accent, long-falling accent
\end{abstract}

